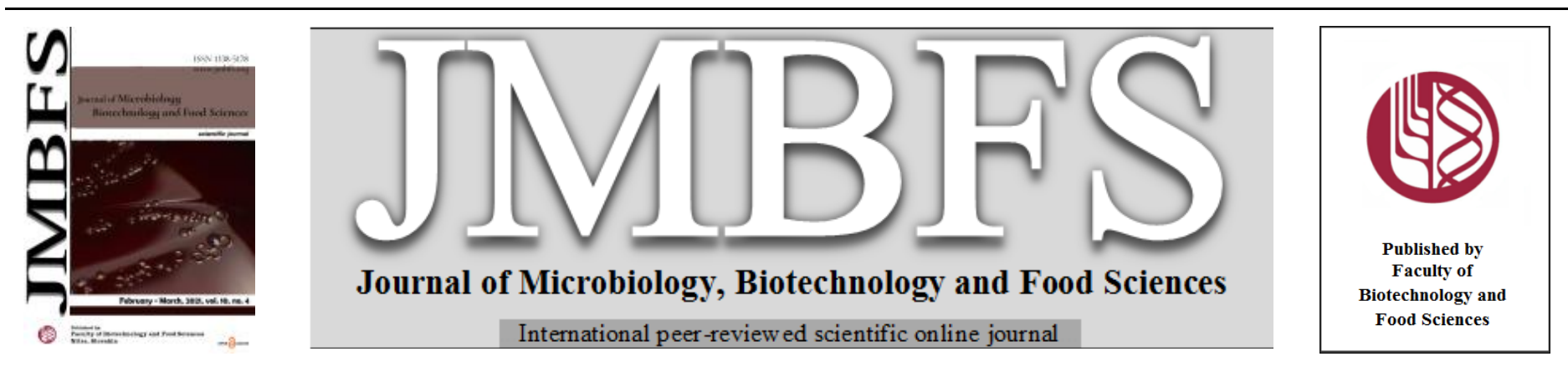

\title{
FREE RADICAL SCAVENGING ABILITY, MECHANISMS OF ACTION AND HEALTH IMPLICATIONS OF OYSTER MUSHROOMS (Pleurotus species)
}

\section{Comfort Olukemi Bamigboye ${ }^{I}$, Iyabo Olunike Omomowo ${ }^{l}$, Micheal Bukola Alao ${ }^{l}$, Joseph Adetunji Elegbede ${ }^{I}$, Elijah Adegoke Adebayo $^{I^{*}}$}

Address(es): Elijah Adegoke Adebayo, $\mathrm{PhD}$

${ }^{1}$ Microbiology Unit, Department of Pure and Applied Biology, Ladoke Akintola University of Technology, P.M.B. 4000, Ogbomoso, Nigeria.

*Corresponding author: eaadebayo@ lautech.edu.ng/egokeadebayo@gmail.com

doi: 10.15414/jmbfs.2021.10.4.636-647

ARTICLE INFO

Received 19. 5. 2020

Revised 6. 10. 2020

Accepted 29. 10. 2020

Published 1. 2. 2021

$\overline{\text { Review }}$

\begin{abstract}
Due to the importance of Oyster mushrooms (Pleurotus species) as a source of food and medicine to man, they have been cultivated both on large and small scales or collected in the wild. The present study evaluated the different antioxidant activities, mechanisms of action and various health implications on human of Oyster mushrooms. Since a single study is not effective in determining the antioxidant property of mushroom, several in vitro assays were reviewed including scavenging activities of DPPH, superoxide, nitric oxide, hydroxyl and ABTS as well as Oxygen radical absorbance capacity (ORAC) activities among others. In vivo assays like enzymatic (catalase (CAT), superoxide dismutase (SOD), glutathione $S$-transferase (GST), glutathione peroxidase (GPx), glutathione reductase (GR), and ascorbate peroxidase (APx) and non-enzymatic (Ascorbic acid, Vitamin E and Glutathione (GSH)); using mice, rats and porcine brain were also reviewed. Oyster mushrooms extract scavenged free radicals and prevented oxidative stress both in vitro and in vivo, and can influence their activities as natural immune boosters and thereby affect human health positively. The review has revealed oyster mushrooms as functional foods enriched with antioxidants and a good potential to oppose the formation of reactive oxygen and nitrogen species, preventing oxidative stress and scavenging free radicals.
\end{abstract}

Keywords: Oyster mushrooms; antioxidant property; human health; biomedical activities; medicinal mushroom

\section{INTRODUCTION}

\section{OYSTER MUSHROOMS; PLEUROTUS SPECIES}

Over the years, mushrooms have been considered as a valuable and nutritional delicacy with dual functions; serving as both foods and medicine to man (Chang and Buswell, 2003; Adebayo et al. 2012b; Bamigboye and Oloke, 2016b). The relationship between man and mushrooms can be traced far back to the ancien past, mainly due to richness in protein, essential amino acids, minerals and polysaccharide metabolites such as beta-glucan (Bamigboye et al., 2013; Bamigboye and Oloke, 2016b). In recent times, however, the oyster mushroom is significant in the mushroom market worldwide, and several of its species are developed in both large and small scales all over the world (Adebayo et al. 2012b). Pleurotus species are cultivated on diverse agricultural wastes since they are more preeminent wood decomposers than other mushroom species (Bamigboye et al., 2019a). The nutritional content of Pleurotus species is, therefore, a function of the genetic make-up, differences in the physical and chemical composition of the growth medium (Akyuz and Kirbag, 2010; Bamigboye et al., 2019a), substrate type, pileus size and harvest time. Pleurotus species reported to be beneficial medicinally are often rich in protein, minerals ( $\mathrm{P}, \mathrm{Ca}, \mathrm{Fe}, \mathrm{Na}$ and $\mathrm{K}$ ) and vitamins (Niacin, Folic acid Riboflavin, and Thiamine) (Caglarimak, 2007; Khan and Tania, 2012), proximate composition (protein, fat, ash, carbohydrates and energy) (Adebayo et al., 2014a; Carneiro et al., 2013; Kalac, 2013). Some sugars, including fructose, mannitol, sucrose, trehalose and fatty acids mainly palmitic, oleic, stearic, linoleic and linolenic acids were found in Pleurotus(Carneiro et al., 2013; Varverde et al., 2015) Oyster mushrooms have high potassium to sodium ratio, making them an ideal food for hypertensive patients and those with heart diseases (Patil et al., 2010). Pleurotus is rich in nutraceutical substances including lectins, which are glycoproteins with antitumor, immunomodulatory and antiproliferative activities. Also, polysaccharides ( $\beta$-glucan, polysaccharopeptides and polysaccharide proteins) have found applications as pharmaceuticals with hepatoprotective (Bamigboye et al., 2019b), anti-inflammatory, immune-enhancing and anticancer properties (Varverde et al., 2015). Heteroglycans of Pleurotus sp. is known to stimulate macrophages and they have antiproliferative and proapoptotic effects on cancer cells (Lavi et al., 2006; Tong et al., 2009). Besides, their phytochemical and phenolic contents such as saponins, alkaloids, steroids, anthraquinones phlobatannins, and flavonoids (Adebayo et al., 2012a) alkaloids, tannins, saponins and flavonoids (Dandapat and Sinha, 2015) antioxidants, and anti-inflammatory activities for Pleurotus species have been reported. Phenolic compounds of different species of Pleurotus are secondary metabolites, which enhance physiological properties of mushrooms like antiinflammatory, antiallergenic, cardioprotective, antiatherogenic, antimicrobial, antithrombotic, antioxidants and can also provide protection against several degenerative disorders (Varverde et al., 2015). Free radicals are released from ultra-violet light, cellular metabolism and polluted air, this then result into inflammation, damage to immune cells and other body cells. Free radicals require intense attention by researchers because they are involved in some disease disorders such as diabetics, heart diseases, respiratory diseases, neurodegenerative disorders, cancers, cataract development and rheumatoid arthritis (Phaniendra et al., 2015). In earlier studies, the therapeutic, biotechnological and nutritional benefits of Pleurotus spp were documented in a review (Correa et al., 2016), likewise, some factors that may affect production of Pleurotus spp have also been discussed (Belletini et al., 2019). More recently, Barbosa et al., (2020) elaborated on the bioactivities of polysaccharides from Pleurotus spp and the development of new extraction methods. Till date, there are very few or no reviews that have collated the promising potency of extracts from Pleurotus spp in scavenging free radicals. Therefore, this present review discussed the antioxidant activities of Pleurotus extracts, their mechanisms of action and implications on human health.

\section{FREE RADICALS AND THEIR SOURCES}

Free radicals are molecular species existing autonomously with an unpaired electron in an atomic orbital. They behave as reductants or oxidants through the donation of an electron to or by accepting an electron from other molecules; they are highly reactive and unstable (Lobo et al., 2010).In a broad sense, free radicals are a type of reactive oxygen species (ROS) and Reactive nitrogen species (RNS) which associate with the oxygen atom $(\mathrm{O})$ and react strongly with other molecules, but not with oxygen (Kurutas et al., 2016). They can react with 
nucleic acid, membrane lipids, enzymes and proteins among others, thereby leading to cellular damage (Adebayo et al., 2014b). Free radicals commonly encountered include hydroxyl radicals, highly reactive oxygen-containing molecules, superoxide anion radicals, nitric oxide radicals singlet oxygen, and various lipid peroxides; lipid hydroperoxide $(\mathrm{ROOH})$, lipid peroxyl radical (ROO), and lipid alkoxyl radical (RO) (Adebayo et al., 2014b; Kurutas et al. 2016). Free radicals are generated both endogenously and exogenously. Humans generate low levels of free radicals during oxidation processes, representing the major endogenous source of free radicals. Metabolic processes such as aerobic respiration and some active organelles including stimulated polymorphonuclear leukocytes, macrophages, mitochondria, peroxisomes, and endoplasmic reticulum and can generate ROS/RNS in living organisms. On the other hand, free radicals that are frequently generated exogenously include ionizing radiations, pesticides and organic solvents, certain pollutants, industrial solvents, cigarette smoke, heavy metal, transition metals, radiation medications such as paracetamol and halothane (Pham-Huyet al., 2008; Adebayo et al., 2012a Adebayo et al., 2014b; Phaniendra et al., 2015; Sanchez, 2017).

\section{FREE RADICAL SCAVENGERS}

The free radicals scavengers are majorly antioxidant compounds that prevent oxidative damages which could result in ageing and life-threatening diseases (Khan et al., 2010). Therefore, antioxidants are defined as chemicals, whether synthetic or natural, capable of preventing the oxidative reactions of free radicals by exchanging its electrons with that of the free radicals for stabilization (Sanchez, 2017). Interestingly, when free radicals occur at low levels in the body system, the innate antioxidant defence systems (glutathione peroxidase, superoxide dismutase, lipase, catalase and other enzymes) can effectively scavenge these free radicals. At higher levels, an antioxidant must be obtained from an external source; mainly dietary. Diets rich in antioxidants include fruits (rich in carotenoids), vitamin $\mathrm{C}$, nuts rich in vitamin $\mathrm{E}$, beta-glucans and most especially mushrooms (Figure 1). Apart from preserving life via the protection of the human body, antioxidants can also serve as food preservatives (Shahidi and Ambigaipalan, 2015). Most of the commonly used synthetic antioxidants such as butylated hydroxyanizole (BHA) and butylated hydroxyltoluene (BHT) are regulated in foods, and other chemicals like ascorbic acids, glutathione, carotenoids, $\alpha$-tocopherol and polyphenol compounds are suspected to be carcinogenic (Jayakumar et al., 2011).

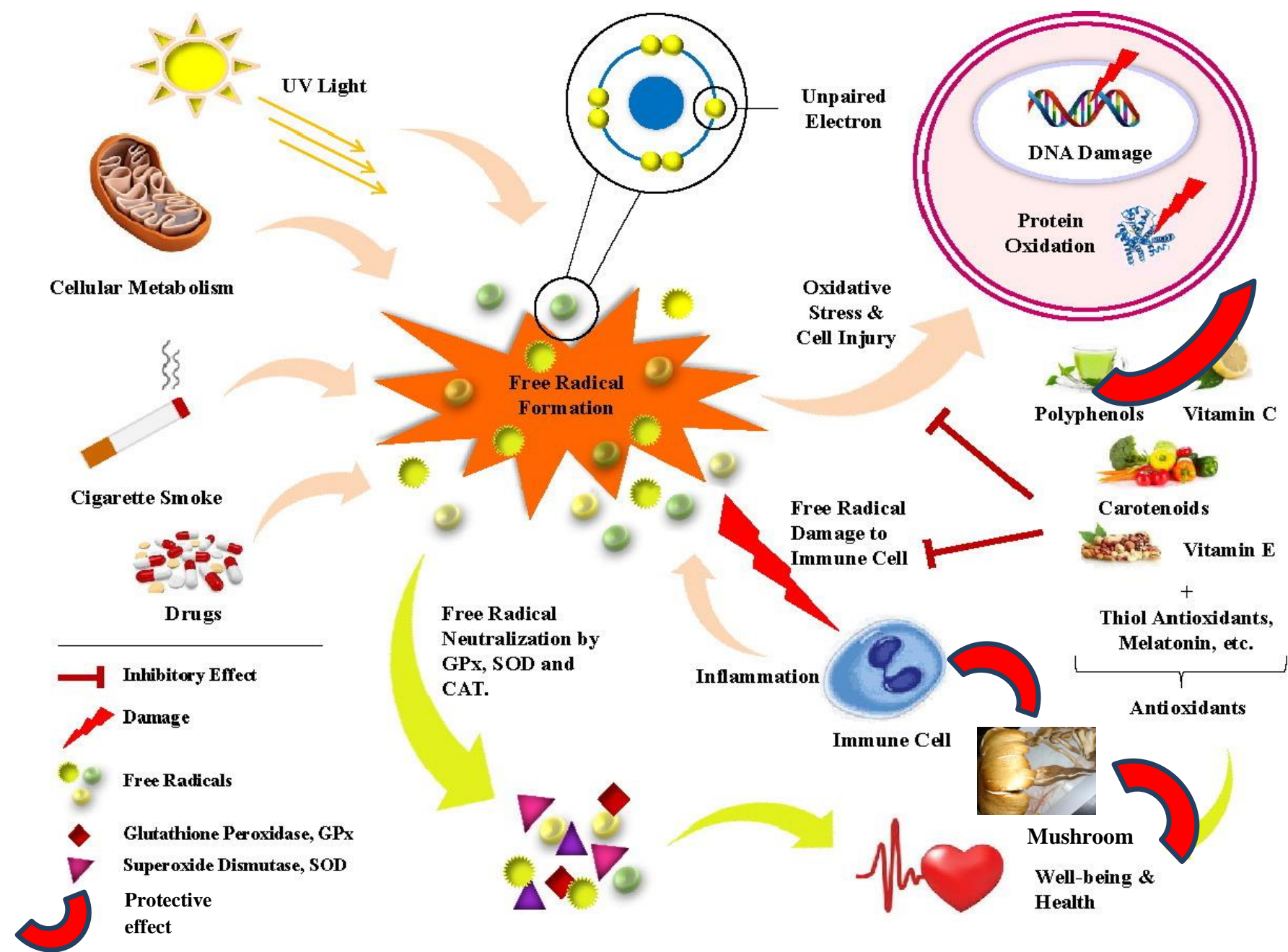

Figure 1 A schematic representation on the sources of free radicals, damages involved and counter-actions by different antioxidants (polyphenols, mushrooms, carotenoids and vitamin C) to maintain human health and well-being.

Thus, the need for research on natural antioxidant compounds, which may be enzymatic and non-enzymatic antioxidant groups cannot be overemphasized Traditionally, some Pleurotus species or their extracts have promising reports in the treatment of some diseases in different parts of Nigeria (Idu et al., 2007; Osemwegie et al., 2010) Japan, China and other Asian countries (Xu et al. 2011). In the past three decades, many polysaccharides and polysaccharideprotein complexes have been extracted from fungi, this includes glycans, heterogeneous and homogeneous polysaccharides and glycan-protein complexes which have been shown to improve the general wellbeing of consumers (Jong $\boldsymbol{e}$ al., 2002). A good number of these bioactive polysaccharides has demonstrated haematological, antitumor, antibiotic, antioxidant, immunomodulatory, antiinflammatory, Hepatoprotective, and antimicrobial effects (Cohen et al., 2002; Hamzah et al., 2014; Adebayo et al., 2014b; Bamigboye et al., 2016a; 2019a) Mushrooms can amass a variety of secondary metabolites and phytochemicals, such as flavonoids, phenolic compounds, polyketides, steroids, terpenes, alkaloids, tannins and saponins (Adebayo et al., 2012b; Dandapat and Sinha, 2015), which are excellent antioxidants. They are not mutagenic and can work synergistically with synthetic and natural antioxidants (Ishikawa et al., 2001). Some non-enzymatic antioxidants, such as vitamin $\mathrm{C}$ (Ascorbate), phenolic compounds, vitamin E (-tocopherol), flavonoids, carotenoids, polyphenols etc (Fereshteh et $\boldsymbol{a l}$., 2017), can act directly as anti-oxidative agents and can be obtained from mushrooms (Adebayo et al., 2012a; Ren et al., 2014; Woldegiorgis et al., 2014; Adebayo et al., 2018). The sufficient intake of mushrooms or mushrooms materials can enhance adequate antioxidant defence, fight against diseases and positively contribute to a good healthy life. 
FREE RADICAL SCAVENGING CAPACITY OF OYSTER MUSHROOMS

\section{PRINCIPLES OF FREE RADICAL SCAVENGING ACTIVITIES OF PLEUROTUS SPECIES}

The need for exogenous means of antioxidants has prompted many studies to investigate the antioxidant potentials of several natural compounds. In this regard, ergothioneine (ERG) contain mainly the amino acid is a natural thiol which is found abundantly in mushroom and is a good source of antioxidant. On this basis, oyster mushroom free radical scavenging principle has been documented (Jayakumar et al., 2011; Dubost et al., 2007).Pleurotus species are a rich source of vitamin $\mathrm{A}, \mathrm{C}$ and $\mathrm{E}$, carotenoid, flavonoids and other bioactive phenolic compounds (Ren et al., 2014; Woldegiorgis et al., 2014), thereby enhancing their free radical scavenging capacity. There are four proposed antioxidants principle mechanisms such as; Preventive antioxidants mechanism: in this case, antioxidants suppress the formation of free radicals by reducing hydrogen peroxide and hydroperoxides to water and alcohols, respectively before they form radicals (Lobo et al., 2010). Catalase and Glutathione peroxidase is implicated in this reaction mechanism and is always in vivo in nature. Another mechanism is through the initiation of chain suppression and breaking of chain propagation reactions. The endogenous antioxidants implicated are vitamin $\mathrm{E}$, vitamin C, phenolic compounds, flavonoids, carotenoids and polyphenols. Repair and de novo antioxidant is another principle mechanism for antioxidants defence. Proteolytic enzymes such as proteases, peptidases and proteinases present in the mitochondria and cytosol in a mammalian cell, detect, destroy and evacuate oxidized proteins and prevent its accumulation (Salehi et al., 2018). The last principle is an adaptation, in this mechanism the endogenous antioxidant empower the cell to design a mechanism to maintain, regulate and adapt itself to the inflow of free radicals not to exert oxidative reactions. For instance, polysaccharide-peptide complex (F22) from the sporophore of Pleurotus abalones was reported to act as an excellent free radical scavenger ( $\mathbf{L i}$ et $\boldsymbol{a l}$. 2007). In another experiment, in vitro demonstration of extract from $P$. ostreatus showed good compelling antioxidant effect by scavenging superoxide and hydroxyl radicals, chelating ferrous ions, impeding lipid peroxidation and decreasing the power of ferric ions (Nau et al., 1998). Also, extracts of $P$. ostreatus exhibited notable in-vivo free radical scavenging action by decreasing the intensity of lipid peroxidation and by improving the non-enzymatic and enzymatic antioxidants action. Polyphenolic compounds in mushroom have been heavily linked to lipid oxidation stabilization and are connected with antioxidan activity (Gulcin-Buyukokuroglu et al., 2003). Extracts of $P$. porrigensat and $P$. florida had interesting scavenging activity against DPPH in contrast to butylhydroxytoluene (BHT), butylated hydroxyanisole (BHA) and tertbutylhydroquinone (TBHQ) (Wong and Chye, 2009) and the reproducible antioxidant activities of Pleurotus species were believed to be owed to the high content of flavonoid, phenol and some antioxidant phytoconstituents of these extracts (Patel et $\boldsymbol{a l}$., 2012). The free radical scavenging properties of oyster mushrooms have been heavily linked to the presence of polysaccharides Mushrooms polysaccharides have been identified as an effective reducing agent ferrous chelator and free radical scavenger. Wang et al. (2016) proposed a likely mechanism for polysaccharide antioxidants to involve polysaccharide conjugations. This implies the combination of polysaccharides with other components such as phytochemicals which together make up the crude polysaccharide. Presence of metal-ion enriched polysaccharide such as Selenium (Se), enhances the polysaccharide antioxidant potentials. Polysaccharide chelating metals bind ions such as copper and ferrous which will inhibit the free radical generations. Another mechanism may occur via the chemical modification of polysaccharides. This may be in the form of sulfation, acetylation, phosphorylation, carboxymethylation and benzoylation which is believed to increase the antioxidant potentials of polysaccharides. Besides, chemical and structural features of polysaccharides such as glycosidic linkage, conformation, molecular mass and chemical compositions have profound effects on thei antioxidant potentials. Mushroom polysaccharides can as well utilize any of the above strategies in scavenging the free radicals.

\section{ANTIOXIDANT MODELS: IN VITRO ASSAYS OF FREE RADICAL SCAVENGING CAPACITY OF PLEUROTUS SPECIES}

Many antioxidant properties of biological materials have been detected using in vitro experimental models. However, the methods can be divided into two main methods namely: hydrogen atom transfer (HAT) and single electron transfer (SET), which was determined based on their reaction mechanisms (Gulcin, 2012 Tan and Lim, 2015). The quenching of free radicals by hydrogen donation is the principle used by HAT, making use of total radical-trapping antioxidan parameter (TRAP), oxygen radical absorbance capacity (ORAC), inhibition of induced low-density lipoprotein (LDL) oxidation, and total oxyradical scavenging capacity assay (Wang etal. 2016). The SET method reduces certain compounds such as metals, carbonyls and radicals by transferring one electron which then results in colour change as evidenced in the reduced compound. This method is utilized in 2,2-diphenyl-1-picrylhydrazyl radical (DPPH) assay, 2,2- azino-bis (3-ethylbenzothiazoline-6-sulphonic acid) diammonium salt (ABTS) assay, Trolox equivalence antioxidant capacity (TEAC) assay, hydrogen peroxide scavenging, ferric ion reducing antioxidant power (FRAP) assay, superoxide radical scavenging (Wang et al., 2016) and many others. High antioxidant activities reported from Pleurotus by different researchers are due to bioactive components such as phytochemicals, enzymes, vitamins, proteins and polysaccharides. The potential of Pleurotus species to show activities in different arrays of antioxidant assays (DPPH, ABTS, ORAC, $\beta$-carotene radica scavenging, superoxide, nitric oxide and hydroxyl scavenging etc.) have been examined and reported.

\section{DPPH Antioxidant assays of Oyster Mushrooms}

DPPH receives an electron or hydrogen radical to develop a stable diamagnetic molecule. Hydrogen donating ability of DPPH is responsible for its high antioxidants potential. The reduction in absorbance of DPPH radical at $517 \mathrm{~nm}$ triggered by antioxidants is said to be the result of the reaction between the radical and antioxidant molecules and thereby leading to the scavenging of the radical via hydrogen donation. Thus, DPPH is typically used as a substrate to estimate scavenging activities of antioxidants (Duh $\boldsymbol{e t}$ al., 1999). Several studies have reported the DPPH scavenging activity of oyster mushroom. High scavenging activities of $81 \%$ in both solid state and submerged fermentation was reported (Adebayo et al., 2014b) for Pleurotus pulmonarius at $10 \mathrm{mg} / \mathrm{mL}$. Sporophore Extract of $P$. djamor grown on rice straw and sawdust mixture inhibited DPPH radicals by 32.8 and $32 \%$ respectively at concentration of 0.5 $\mathrm{mg} / \mathrm{ml}$ (Rich et al., 2016). Also, intracellular and extracellular polysaccharide fractions of mutants strains of $P$. tuber-regium effectively scavenged DPPH radicals with an $\mathrm{EC}_{50}$ of less than $0.1 \mu \mathrm{g}$ (Bamigboye et al., 2016). The DPPH scavenging and $\mathrm{EC}_{50}$ of the following Pleurotus species: pulmonarius, levis, ostreatus, tuber-regium, squarrosulus, sajor-cajor, euos, eryngii and cystidiosus have been reported by several studies (Tab 1). Arbaayah and Kalsom (2013) reported the antioxidant potentials of oyster mushrooms in the DPPH free radical scavenging activity test with $\mathrm{IC}_{50}$ that ranged between $4.20-12.0 \mathrm{mg} / \mathrm{ml}$ for $P$ pulmonarius, $P$. djamor var. roseus, $P$. djamorvar. djamor,and $P$. ostreatus Moreover,the Polysaccharide of Pleurotus ostreatus (Jacq.) P. Kumm demonstrated a concentration dependent DPPH free radical scavenging activity (within $0.2-5.0 \mathrm{mg} / \mathrm{ml}$ ), with highest activity obtained at higher concentrations which tallied with that of ascorbic acid at $1.2 \mathrm{mg} / \mathrm{ml}$ equivalent to $72.23 \%$ (Pk et al., 2019). The scavenging capacities of intracellular mycelia polysaccharide of $P$. florida, $P$. sajor-caju, $P$. eryngiiand $P$. ostreatus ranged from $16-71.29 \%$ within the concentrations of $1-10 \mathrm{mg} / \mathrm{ml}$ (Dundaret al., 2013). The highest scavenging potential of $81.3 \%$ at $200 \mu \mathrm{g} / \mathrm{ml}$ was displayed by methanolic extract from $P$. ostreatus(Elmastas et al., 2007). In another study, up to 92.2 and $74.4 \%$ of DPPH radicals were scavenged by $5 \mathrm{mg} / \mathrm{ml}$ of ethanolic extracts of $P$. eryngii and $P$. ostreatus respectively (Lo, 2005). Additionally, Talkad et al. (2015) described that Lovastatin extract of Pleurotus ostreatus displayed noteworthy antioxidant action when compared with Quercetin (a typical antioxidant), with $\mathrm{IC}_{50}$ values of 3.5 and $7.5 \mu \mathrm{g} / \mathrm{ml}$ respectively in a DPPH free radical scavenging assay. Puttaraju et al. (2006), reported the antioxidant potentials of aqueous and methanolic extracts of $P$. sajor-caju, and the $\mathrm{IC}_{50}$ values attained in $\mathrm{DPPH}$ free radical scavenging assay were 1.80 and $2.50 \mathrm{mg} / \mathrm{ml}$ respectively. Also, the $\mathrm{EC}_{50}$ values of DPPH free radical scavenging of Pleurotus eryngii and methano extract of $P$. eous were 9.21 and $4.2 \mathrm{mg} / \mathrm{ml}$ respectively (Reis et al., 2014; Sudha et al., 2012). Also, Kalyoncu et al. (2010) opined that ethanolic extract of Pleurotusostreatus and $P$. eryngiihad effective DPPH free radical scavenging activity. Jeena et al. (2016) studied the DPPH radical scavenging activity of methanolic extract from three Pleurotus sp. viz P. sapidus, $P$. ostreatus, and $P$. sajor-caju. The authors specified that $P$. sajor-cajuhad the least EC ${ }_{50}$ which was $2 \mathrm{mg} / \mathrm{ml}$ concentration.Debnathet al. (2017) reported the antioxidant potentials of methanolic extracts of mycelia of somePleurotusspecies which are P. sapidus (DMRP-4), P. membranaceus Massee. (DMRP-189),P. sajor-caju (Fr.) Singer (DMRP-112), P.ostreatus (DMRP-262), P. florida (Mont.) Singer (DMRP 88), P. flabellatus (Berk. \& Broome) Sacc (DMRP-5), P. hypsizygus ulmarius (Bull.) Redhead (DMRP-115), P. eryngii (DMRP-135), P. djamor (DMRP-205) and $P$. citrinopileatus Singer (DMRP-10). In the study, the DPPH free radical scavenging experiment revealed that the mycelia methanolic extracts of the ten Pleurotus species displayed antioxidant activities within the range of 62.97 $92.05 \%$ at $8.0 \mathrm{mg} / \mathrm{ml}$, and the strongest $\mathrm{EC}_{50}$ was displayed by $P$. sapidus at a concentration of $0.352 \mathrm{mg} / \mathrm{ml}$ compared to the other nine Pleurotus species. Also, Acharya et al. (2017) reported that Pleurotus djamor, had an $\mathrm{EC}_{50}$ value of 0.653 $\mathrm{mg} / \mathrm{ml}$ when evaluated using DPPHantioxidant assay. The DPPH antioxidants assay by extracts of Pleurotus species has revealed its potentials as dominant reducing agents by using single electron transfer strategy, which confirmed Pleurotus extract as powerful antioxidant agents. This prospect make Pleurotus mushrooms play essential roles in scavenging radicals, act as immune boosters, control of some diseases as well as taken as functional foods. 
Superoxide, Nitric Oxide and Hydroxyl Scavenging Activities of Oyster Mushrooms

The superoxide radical is very dangerous to some cell components because of its ability to produce more reactive oxygen species (Dundar et al., 2013). The superoxide radical-scavenging activity of the cultured mycelia extracts of Pleurotus eryngii, P. ostreatus, $P$. florida, and P.sajor-caju reported as percentage inhibitions which ranged from $67.92-76.14 \%$ at $10 \mathrm{mg} / \mathrm{ml}$. This can result from the interrelations ofthediverse flavonoids in the extracts (Zhishen et al., 1999). Also, Jayakumar et al. (2009) studied and reported that the superoxide anion radical scavenging action of ethanolic extract of $P$. ostreatus basidiocarp was $60.02 \%$. The extracts of $P$. squarrosulus had high superoxide and nitric oxide scavenging activities with $\mathrm{EC}_{50}$ of $8.63 \mathrm{mg} / \mathrm{ml}$ and $4.46 \mathrm{mg} / \mathrm{m}$ respectively (Pal et al., 2010). Extracts of $P$. ostreatus inhibited hydroxyl compound by $50 \%$ at $8 \mathrm{mg} / \mathrm{ml}$ (Jayakumar et al., 2009). Various extracts of $P$. floridaand $P$. pulmonarius had varying hydroxyl scavenging activities as reported by (Ajith and Janadhanan, 2007). The superoxide, nitric oxide and hydroxyl scavenging activities of oyster mushrooms are also presented in Table 2.

\section{ABTS Radicals Scavenging Potentials of Oyster Mushroom}

A couple of studies have reported the prospect of Oyster mushrooms and their metabolites in mopping up or scavenging ABTS radicals which further emphasize their usefulness as natural antioxidants. Extracts of $P$. euos, $P$. ostreatus, $P$. eryngii, and $P$. cystidiosus were reported to possess potentials to scavenge ABTS radicals although at low concentrations (Kongkla and Poeaim, 2016), while higher scavenging activities were reported by Adebayo et al. (2018) for extracts of $P$. levis, P. ostreatus, $P$. tuber-regium, and P. pulmonarius . Also, Pk et al. (2019) reported that polysaccharide of $P$. ostreatus displayed significant ABTS radicals scavenging activity $-81.02 \%$, which equalled the activities of ascorbic acid at $1.4 \mathrm{mg} / \mathrm{ml}$. The antioxidant potentials of various Pleurotus mushroom species against ABTS radicals are also reported in Table 3.

Table 1 DPPH Scavenging Activity of Oyster Mushrooms along with solvent, $\mathrm{EC}_{50}$ values, highest scavenging activity and cited literatures

\begin{tabular}{|c|c|c|c|c|}
\hline Mushroom & Extractant & $\begin{array}{c}\text { Concentration } \\
(\mathrm{mg} / \mathrm{mL})\end{array}$ & $\begin{array}{c}\text { DPPH } \\
\text { Scavenging } \\
\text { assay }(\%)\end{array}$ & Reference \\
\hline P. pulmonarius LAU 09 & - & $\begin{array}{c}5.0 \\
10.0\end{array}$ & $\begin{array}{l}78.4 \\
81.0\end{array}$ & Adebayo et al. (2012b) \\
\hline & Methanol & $\begin{array}{c}5.0 \\
10.0\end{array}$ & $\begin{array}{l}78.0 \\
81.0\end{array}$ & Adebayo et al. (2014b) \\
\hline P. pulmonarius $\mathrm{CP}-16$ & Hydro-alcohol & 0.0007 & $50.0\left(\mathrm{EC}_{50}\right)$ & Adebayo et al. (2018) \\
\hline P. pulmonarius CP-799 & Hydro-alcohol & 0.00049 & $50.0\left(\mathrm{EC}_{50}\right)$ & Adebayo et al. (2018) \\
\hline P. cornucopiae $\mathrm{NE} 02$ & Methanol & $\begin{array}{c}5.0 \\
10.0\end{array}$ & $\begin{array}{l}35.0 \\
68.0\end{array}$ & Adebayo et al. (2014b) \\
\hline P. ostreatus LAU 10 & Methanol & $\begin{array}{c}5.0 \\
10.0\end{array}$ & $\begin{array}{l}60.0 \\
71.0\end{array}$ & Adebayo et al. (2014b) \\
\hline P. levis CP-30 & Hydro-alcohol & 0.00051 & $50.0\left(\mathrm{EC}_{50}\right)$ & Adebayo et al. (2018) \\
\hline P. ostreatus CP-50 & Hydro-alcohol & 0.00105 & $50.0\left(\mathrm{EC}_{50}\right)$ & Adebayo et al. (2018) \\
\hline P. ostreatus CP-800 & Hydro-alcohol & 0.00063 & $50.0\left(\mathrm{EC}_{50}\right)$ & Adebayo et al. (2018) \\
\hline P. tuber-regium $\mathrm{CP}-182$ & Hydro-alcohol & 0.00168 & $50.0\left(\mathrm{EC}_{50}\right)$ & Adebayo et al. (2018) \\
\hline P. squarrosulus & $\begin{array}{l}\text { Cold water } \\
\text { Hot water } \\
\text { Methanol }\end{array}$ & $\begin{array}{c}0.465 \\
0.304 \\
1.5\end{array}$ & $\begin{array}{l}50.0\left(\mathrm{EC}_{50}\right) \\
50.0\left(\mathrm{EC}_{50}\right) \\
50.0\left(\mathrm{EC}_{50}\right)\end{array}$ & Pal et al. (2010) \\
\hline P. sajor-caju & Methanol & 5.2 & $50.0\left(\mathrm{EC}_{50}\right)$ & Kongkla \& Poeaim (2016) \\
\hline P. sajor-caju & Methanol & 6.0 & 61.0 & Ramkumar et al. (2010) \\
\hline P. euos & $\begin{array}{l}\text { Methanol } \\
\text { Hexane }\end{array}$ & $\begin{array}{l}5.4 \\
0.5\end{array}$ & $\begin{array}{c}50.0\left(\mathrm{EC}_{50}\right) \\
32.0\end{array}$ & Kongkla \& Poeaim (2016) \\
\hline P. eryngii & Methanol & 8.4 & $50.0\left(\mathrm{EC}_{50}\right)$ & Kongkla \& Poeaim (2016) \\
\hline P. cystidiosus & Methanol & 9.1 & $50.0\left(\mathrm{EC}_{50}\right)$ & Kongkla \& Poeaim (2016) \\
\hline
\end{tabular}

EC $_{50}: 50 \%$ Effective Concentration; Fermentation: solid state

Table 2 Superoxide (SO), Nitric oxide (NO) and Hydroxyl (OH) Scavenging Assay of Oyster Mushroom

\begin{tabular}{|c|c|c|c|c|c|c|}
\hline \multirow[t]{3}{*}{ P. squarrosulus } & Cold water & 1.830 & 0.360 & 0.364 & $50.0\left(\mathrm{EC}_{50}\right)$ & \multirow{3}{*}{ Pal et al. (2010) } \\
\hline & Hot water & 1.473 & 0.320 & 0.268 & $50.0\left(\mathrm{EC}_{50}\right)$ & \\
\hline & Methanol & 8.630 & 4.460 & 0.706 & $50.0\left(\mathrm{EC}_{50}\right)$ & \\
\hline \multirow{3}{*}{$\begin{array}{c}\text { P. ostreatus } \\
P . \text { florida }\end{array}$} & Ethanol & 8.000 & NR & 8.000 & $50.0\left(\mathrm{EC}_{50}\right)$ & \multirow{3}{*}{$\begin{array}{c}\text { Jayakumar et al. (2009) } \\
\text { Ajith and Janardhanan } \\
\text { (2007) }\end{array}$} \\
\hline & Methanol & NR & NR & 0.263 & $50.0\left(\mathrm{EC}_{50}\right)$ & \\
\hline & Aqueous & NR & NR & 0.263 & & \\
\hline$P \cdot$ pulmonarius & Methanol & NR & NR & 0.476 & $50.0\left(\mathrm{EC}_{50}\right)$ & $\begin{array}{l}\text { Ajith and Janardhanan } \\
\text { (2007) }\end{array}$ \\
\hline
\end{tabular}

$\mathrm{EC}_{50}: 50 \%$ Effective Concentration; Fermentation: solid state; NR: Not Recorded

Table 3 ABTS Scavenging Activity of Oyster Mushrooms along with solvent, $\mathrm{EC}_{50}$ values, highest scavenging activity and cited literatures

\begin{tabular}{|c|c|c|c|c|}
\hline Mushroom & Extractant & $\begin{array}{c}\text { Concentration } \\
(\mathrm{mg} / \mathrm{mL})\end{array}$ & $\begin{array}{c}\text { ABTS Scavenging } \\
\text { assay }(\%)\end{array}$ & Reference \\
\hline P. levis CP-30 & Hydro-alcohol & 0.00050 & $50.0\left(\mathrm{EC}_{50}\right)$ & Rich et al. (2016) \\
\hline P. ostreatus CP-50 & Hydro-alcohol & 0.00042 & $50.0\left(\mathrm{EC}_{50}\right)$ & Rich et al. (2016) \\
\hline P. ostreatus CP-800 & Hydro-alcohol & 0.00024 & $50.0\left(\mathrm{EC}_{50}\right)$ & Rich et al. (2016) \\
\hline P. pulmonarius $\mathrm{CP}-16$ & Hydro-alcohol & 0.00035 & $50.0\left(\mathrm{EC}_{50}\right)$ & Rich et al. (2016) \\
\hline P. pulmonarius CP-799 & Hydro-alcohol & 0.00037 & $50.0\left(\mathrm{EC}_{50}\right)$ & Rich et al. (2016) \\
\hline \multirow[t]{2}{*}{ P. tuber-regium $\mathrm{CP}-182$} & Hydro-alcohol & 0.00050 & $50.0\left(\mathrm{EC}_{50}\right)$ & Rich et al. (2016) \\
\hline & Methanol & 5.10 & $50.0\left(\mathrm{EC}_{50}\right)$ & Kongkla \& Poeaim (2016) \\
\hline P. sajor-caju & Methanol & 4.51 & $50.0\left(\mathrm{EC}_{50}\right)$ & Kongkla \& Poeaim (2016) \\
\hline P. eous & Methanol & 3.92 & $50.0\left(\mathrm{EC}_{50}\right)$ & Kongkla \& Poeaim (2016) \\
\hline P. eryngii & Methanol & 6.98 & $50.0\left(\mathrm{EC}_{50}\right)$ & Kongkla \& Poeaim (2016) \\
\hline P. cystidiosus & Methanol & 7.18 & $50.0\left(\mathrm{EC}_{50}\right)$ & Kongkla \& Poeaim (2016) \\
\hline
\end{tabular}

$\mathrm{EC}_{50}: 50 \%$ Effective Concentration 


\section{Metal Chelating ability of Oyster Mushrooms}

The initial development of radicals can be catalyzed by transition metals Transition metals can be made steady by chelating agents in living systems to restrain free radicals generation, as a result limiting the induction of free radical damage (Dundar et al., 2013). The chelating potential of an extract provides a means of preventing the generation of free-radical and iron-overload via the chelation of metal ions. Also, metal ion chelating ability played an important action in antioxidant mechanism, since ferrous ions are the most efficient pro-oxidants in food structures. The effectiveness of extracts to impede the development of ferrozine and ferrous complex will suggest their capacity for chelating activities (Debnath et al., 2017). The oxidative loss and iron-overload in the systems may be prevented by chelating agents (Lai et al., 2001). Chelating activities of $P$. pulmonarius, $P$. citrinopileatus and $P$. florida at $1.0 \mathrm{mg} / \mathrm{ml}$ were reported to range from 78.14-82.07 \% which were significantly higher than EDTA $(50.66 \%)$ and citric acid $(46.84 \%)$ (Khatun et al., 2015). According to Lee et al. (2007), the chelating abilities of $P$. citrinopileatus extracted in ethanol, cold and hot water at $5 \mathrm{mg} / \mathrm{ml}$ were 46 , 67 and, 82\% respectively. Jayakumar et al. (2009) reported that ethanolic extracts of P.ostreatus fruiting body had $60.68 \%$ scavenging activity at $10 \mathrm{mg} / \mathrm{ml}$ concentration. Also, the chelating activity of ethanolic extracts of fruiting bodies of $P$. ostreatus and P. eryngii at $5 \mathrm{mg} / \mathrm{ml}$ was described to be 41.4 and $64.0 \%$ (Lo, 2005).Dundar et al. (2013) reported that at all of the concentrations ranging from $2.0-10 \mathrm{mg} / \mathrm{ml}$, ethanolic extracts of mycelia of $P$. florida, $P$. eryngii, $P$. sajor-caju, and $P$. ostreatus showed higher chelating activities than the standard antioxidants (BHT and $\alpha$-tocopherol) with percentage inhibition of 57.3- 69.5\% at $10 \mathrm{mg} / \mathrm{ml}$. Mau et al. (2001) reported that methanolic extracts of ear mushroom was able to chelate $85.1-96.5 \%$ of ferrous ions at a concentration of $5 \mathrm{mg} / \mathrm{mL}$, thereby they are excellent chelators. An ethanolic extract of $P$. eryngii had a high chelating activity of approximately $75 \%$ at an $\mathrm{IC}_{50}$ of $1.00 \mathrm{mg} / \mathrm{ml}$ (Yildirim et al., 2012).

\section{Ferric Reducing Ability and Power of Oyster Mushroom}

The potential antioxidant activity of a compound can be determined by its reducing capacity. The various mechanisms such as chain initiation prevention, peroxides decompositions, transition metal ion binding catalysts, hydrogen abstraction discontinued, reductive capacity and scavenging of free radicalhave been attributed toputative antioxidant activity of various antioxidants substances(Gulcin et al., 2003). Antioxidant compounds can transform the oxidized form of iron in ferricyanide $\left(\mathrm{Fe}^{3+}\right)$ to ferrous $\left(\mathrm{Fe}^{2+}\right)$ ion. The electron transfer ability is associated with its reducing power and may serve as animportantpointer tointeresting antioxidant activity (Debnathet al., 2017).P. sajor-caju and $P$. ostreatus were reported to have high scavenging power, 1.980 and 1.780 respectively at $10 \mathrm{mg} / \mathrm{ml}$ concentration(Jeena et al., 2016). According to Sudha et al. (2012), the scavenging powers of hot water, methanolic, and ethyl acetate fractions of $P$. eousat $10 \mathrm{mg} / \mathrm{ml}$ was quite high, being 1.632 , 1.132 , and 1.950 respectively. Also, $P$. pulmonarius, $P$.djamor var. djamor, $P$. ostreatus and $P$. djamor var. roseus were reported to display substantial reducing activities at concentrations between 2 and $10 \mathrm{mg} / \mathrm{ml}$ depending on their capacity to reduce ferricyanide complex to ferrous form which varied from 0.29 to 1.23 Although the values obtained for synthetic antioxidants, Quercetin and BHA serving as the standards were appreciably higher by two folds than those of the mushroom extracts (Arbaayah and Kalsom, 2013). Khatun et al. (2015) reported that the optical density at $700 \mathrm{~nm}$ in evaluating the reducing power of $P$. citrinopileatus, $P$. pulmonarius, and $P$. florida showed values which range from $0.073-0.217$ at $1.0 \mathrm{mg} / \mathrm{ml}$ concentration which was appreciably higher than ascorbic acid. Debnathet al. (2017) showed that the reducing powers of methanolic extracts of Pleurotus species mycelia tested (which are $P$. sajor caju (DMRP-112), P. sapidus (DMRP-4), P. ostreatus (DMRP-262), $P$ membranaceus(DMRP-189), P. florida (DMRP-88), P. flabellatus (DMRP-5), $P$. hypsizygus ulmarius (DMRP-115), P. eryngii (DMRP-135), P. djamor (DMRP-205) and P. citrinopileatus (DMRP-10)) were excellent, increasing steadily with increasing concentrations $(0.5-8 \mathrm{mg} / \mathrm{ml})$. Also, it was shown that $P$. sajor-caju displayed the highest ferric reducing power of $0.17-1.08$ at 8 $\mathrm{mg} / \mathrm{ml}$. The scavenging activity of ethanol, hot, and cold water extracts from the sporophore of $P$. citrinopileatusat $5 \mathrm{mg} / \mathrm{ml}$ were in the range of $1.03-1.10$ (Lee et al. 2007) and these were higher than those of the mycelia and filtrate. Dundar et al. (2013) reported that reducing power within $0.74-0.86$ were recorded for four Pleurotus sp. (P. florida, P. sajor-caju, P. ostreatus and $P$. eryngii) at $10 \mathrm{mg} / \mathrm{ml}$ and these were higher compared to results for both BHA and BHT excluding $\alpha$-tocopherol with reducing powers of 0.99 . The extracts of $P$. squarrosulus isolated from laterite region in the wild had high chelating and reducing power at $1.225 \mathrm{mg} / \mathrm{mL}$ and $13 \mathrm{mg} / \mathrm{mL}$ respectively (Pal et al., 2012). $P$. eous also reportedly had reducing power of $0.4 \%$ while $P$. sajor-caju and $P$. platypus had $0.2 \%$ at $6 \mathrm{mg} / \mathrm{ml}$ (Rankumar et al., 2010). It has been earlier proven that chemically synthesized antioxidants, among which are, BHA, BHT and TBHQ, are mutagenic. Thus, alternative antioxidants that are derived from natural resources are quite interesting and easily acceptable by consumers (Lo, 2005; Elmastas et al., 2007). The ferrous ion chelating potential and reducing power of oyster mushrooms are presented in Table 4.

\section{$\beta$-Carotene Radical Scavenging and Antioxidant Capacity by Phosphomolybdenum Method}

Few studies have examined the antioxidant prospect of Oyster mushrooms and their metabolites by the Phosphomolybdenum method and as well reported their potentials in scavenging $\beta$-carotene radical. In vitro analysis of the radicalproducing systems have acknowledged the ability of $\beta$-carotene to reduce free radicals viacertain processes which include abstraction of hydrogen, addition of the radical to the carotenoid and/or transfer of electron(Krinsky, 2001) Generally, mushrooms are known to have an appreciable quantity of $\beta$-carotene, vitamins $\mathrm{A}$ and $\mathrm{C}$, all of which protect against cellular damage due to their excellent antioxidant power(Murcia et al., 2002). The methanolic extract of $P$. cornucopiae and $P$. sapidus scavenged $\beta$-carotene radicals by $98 \%$ while $P$. pulmonarius and $P$. ostreatus scavenged radical $\beta$-carotene by $62 \%$ (Adebayo et al., 2014b). Submerged fermentation of $P$. pulmonarius showed high antioxidant activity of $87 \mu$ moles $/ 100 \mathrm{~g}$ as determined by phosphomolybdenum method while $P$. sapidus and $P$. ostreatus had $28 \mu$ moles $/ 100 \mathrm{~g}$. The $\mathrm{EC}_{50}$ for $\beta$-carotene radical scavenging activities for extracts from $P$. pulmonarius, $P$. ostreatus, $P$. levis, $P$. tuber-regium and $P$. squarrosulus have also been reported (Adebayo et al. 2018) Also, according to Dundar et al. (2013), the ethanolic mycelial extract of of $P$. eryngii, $P$. ostreatus, $P$. sajor-caju and $P$. florida, exhibited inhibition of peroxidation in a $\beta$-carotene-linoleic acid system at a concentration of $0.5-10$ $\mathrm{mg} / \mathrm{mL}$ within the range of $34.04-62.12 \%$.The $\beta$-carotene radical scavenging and antioxidant capacity measured by phosphomolybdenum methods are presented in Table 5.

Table 4 Chelating Ability of Ferrous Ions and Reducing Power Assay of Oyster Mushroom

\begin{tabular}{|c|c|c|c|c|c|}
\hline Mushroom & Extractant & $\begin{array}{c}\text { Chelating } \\
\text { ability } \\
(\mathrm{mg} / \mathrm{mL}) \\
\end{array}$ & $\begin{array}{c}\text { Reducing } \\
\text { power } \\
(\mathbf{m g} / \mathbf{m L}) \\
\end{array}$ & $\begin{array}{c}\text { Reducing } \\
\text { power } \\
(\%) \\
\end{array}$ & Reference \\
\hline \multirow{3}{*}{ P. squarrosulus } & Cold water & 0.090 & 1.33 & $50.0\left(\mathrm{EC}_{50}\right)$ & \multirow{3}{*}{ Pal et al. (2010) } \\
\hline & Hot water & 0.075 & 1.14 & $50.0\left(\mathrm{EC}_{50}\right)$ & \\
\hline & Methanol & 1.225 & 13.00 & $50.0\left(\mathrm{EC}_{50}\right)$ & \\
\hline P. ostreatus & Ethanol & 6.000 & ND & $50.0\left(\mathrm{EC}_{50}\right)$ & Jayakumar et al. (2009) \\
\hline P. sajor-caju & Methanol & NR & 6.00 & 0.20 & Ramkumar et al. (2010) \\
\hline P. euos & Methanol & NR & 6.00 & 0.40 & Ramkumar et al. (2010) \\
\hline P. florida & Methanol & NR & 6.00 & 0.22 & Ramkumar et al. (2010) \\
\hline P. platypus & Methanol & NR & 6.00 & 0.20 & Ramkumar et al. (2010) \\
\hline P. djamor & Methanol & NR & 6.00 & 0.30 & Ramkumar et al. (2010) \\
\hline
\end{tabular}

EC $_{50}: 50 \%$ Effective Concentration; Fermentation: solid state; NR: Not Recorded

Table $5 \beta$ - Carotenes Radical Scavenging and Antioxidant Capacity (as Equivalent to Ascorbic Acid) by Phosphomolybdenum Method of Oyster Mushroom

\begin{tabular}{|c|c|c|c|c|c|c|}
\hline \multirow{6}{*}{ P. pulmonariusLAU 09} & & & 1.0 & NR & 25.6 & \multirow{3}{*}{ Adebayo et al. (2012b) } \\
\hline & Submerge & - & 2.0 & 62.1 & NR & \\
\hline & & & 5.0 & 78.4 & 87.1 & \\
\hline & \multirow{3}{*}{ Solid state } & \multirow{3}{*}{ Methanol } & 1.0 & NR & 25.5 & \multirow{3}{*}{ Adebayo et al. (2014b) } \\
\hline & & & 2.0 & 62.0 & NR & \\
\hline & & & 5.0 & 78.0 & 87.0 & \\
\hline P. pulmonarius $\mathrm{CP}-16$ & Solid state & Hydro-alcohol & $>0.005$ & $50.0\left(\mathrm{EC}_{50}\right)$ & NR & Adebayo et al. (2018) \\
\hline P. pulmonarius $\mathrm{CP}-799$ & Solid state & Hydro-alcohol & 0.00022 & $50.0\left(\mathrm{EC}_{50}\right)$ & NR & Adebayo et al. (2018) \\
\hline P. sapidus NE 07 & Solid state & Methanol & 1.0 & NR & 28.0 & Adebayo et al. (2014b) \\
\hline
\end{tabular}




\begin{tabular}{|c|c|c|c|c|c|c|}
\hline & & & 2.0 & 98.0 & NR & \\
\hline & & & 5.0 & 95.0 & 57.0 & \\
\hline & & & 1.0 & NR & 34.0 & \\
\hline \multirow[t]{3}{*}{ P. cornuсорiae NE 02} & Solid state & Methanol & 2.0 & 70.0 & NR & Adebayo et al. (2014) \\
\hline & & & 5.0 & 98.0 & 69.0 & \\
\hline & & & 1.0 & NR & 28.0 & \\
\hline \multirow[t]{2}{*}{ P. ostreatusLAU 10} & Solid state & Methanol & 2.0 & 62.0 & NR & Adebayo et al. (2014b) \\
\hline & & & 5.0 & 88.0 & 72.0 & \\
\hline P. ostreatusCP-50 & Solid state & Methanol & 0.00034 & $50.0\left(\mathrm{EC}_{50}\right)$ & NR & Adebayo et al. (2018) \\
\hline P. ostreatus CP-800 & Solid state & Methanol & 0.00017 & $50.0\left(\mathrm{EC}_{50}\right)$ & NR & Adebayo et al. (2018) \\
\hline P. levis $\mathrm{CP}-30$ & Solid state & Methanol & 0.00059 & $50.0\left(\mathrm{EC}_{50}\right)$ & NR & Adebayo et al. (2018) \\
\hline \multirow[t]{2}{*}{ P. tuber-regium $\mathrm{CP}-182$} & Solid state & Methanol & 0.00016 & $50.0\left(\mathrm{EC}_{50}\right)$ & NR & Adebayo et al. (2018) \\
\hline & & Cold water & 0.554 & $50.0\left(\mathrm{EC}_{50}\right)$ & NR & \\
\hline \multirow[t]{2}{*}{ P. squarrosulus } & Solid state & Hot water & 0.550 & $50.0\left(\mathrm{EC}_{50}\right)$ & NR & Pal et al. (2010) \\
\hline & & Methanol & 3.793 & $50.0\left(\mathrm{EC}_{50}\right)$ & NR & \\
\hline
\end{tabular}

$\mathrm{EC}_{50}: 50 \%$ Effective Concentration. NR: Not Recorded

\section{Total Phenolic Content of Oyster Mushroom}

Phenolic compounds are aromatic hydroxylated compounds which have one or more aromatic rings and one or more hydroxyl groups. They include hydroxybenzoic acids, phenolic acids, flavonoids, hydroxycinnamic acids, tannins, lignans, oxidized polyphenols and stilbenes (Sanchez, 2017). It has been established that phenolic compounds demonstrate free radical scavenging effect in the body, functioning as peroxide decomposers, free radical inhibitors, oxygen scavengers or metal in activators. Mushrooms in general contain an appreciable quantity of polyphenols at different concentrations ranged from 3.62 to 6.25 $\mathrm{mg} / \mathrm{ml}$ (Ramesh and Pattar, 2010; Barros et al., 2008). Phenolic compounds can be found and extracted from different mushroom, both mycelia and fruiting body, for instance, the mycelium of Pleurotus albidus(Gambato et al., 2016) and the fruit bodies of Pleurotus cornucopiae(Kolayli et al., 2012). Phenolic substances, including phenolic acids and flavonoids, are reported to have antioxidant activity. Also, phenolic compounds in mushrooms are known as exceptional synergists and antioxidants which are not mutagenic (Jayakumar et al., 2011). Phenols are vital plant components owing to the presence of hydroxyl groups, hence having scavenging potential (Dundar et al., 2013). Some studies have convincingly shown that eating phenol-rich foods can lower the menace of cardiovascular diseases by reducing the development of atherosclerosis since they function as antioxidants (Singla et al., 2010; Halliwell and Gutteridge, 2015). Dietary phenolic compounds have been said to have the ability to trigger some biologica mechanisms, such as chelation of metals, free-radical scavenging, and regulation of enzymatic activity; they likewise affect the initiation of transcription factors, signal transduction and gene expression (Srinivasan et al., 2005). They have received unique attention due to their purported function in the inhibition of some human illnesses(Nardini and Ghiselli, 2004). The presence of phenols in mushrooms has contributed significantly to theirefficiency at scavenging peroxy radicals (Murcia et al., 2002). The total phenolic content of Pleurotus sp has been described in several studies as either tallic acid, gallic acid or ascorbic acid equivalent or percentage (Tab 6). Extracts of $P$. djamor had a reportedly high phenolic content of 982 ascorbic acid equivalents (Rankumar et al., 2010), while extracts of $P$. tuber-regium had 0.05 gallic acid equivalents. This great difference in the phenolic content could be linked to the variation in the standard used in reporting the phenolic content equivalence. Arbaayah and Kalsom (2013) reported that the number of total phenolics in $P$. djamor var. djamor, $P$. pulmonarius, $P$. ostreatusand $P$. djamor var. roseus, ranged from 39.36 to $51.94 \mathrm{mg} \mathrm{TAE} / \mathrm{g}$ of dry weight of the crude extract. Also, the total phenolic content of Pleurotus ostreatus was $0.09 \mathrm{mg} / \mathrm{g}$, while that of Pleurotus eryngi was $0.03 \mathrm{mg} / \mathrm{g}$ of dry weight (Kim et al., 2008). The total phenol content in $P$. sajor-caju and $P$. djamorwas 14.43 and $13.22 \mathrm{mg} / \mathrm{g}$ of extract respectively (Puttaraju et al., 2006) while $P$. ostreatus was estimated to havea total phenolic content of $0.71 \mathrm{mg} / \mathrm{g}$ dry weight (Jayakumar, 2008). Khatun et al. (2015) showed that the total phenol content of $P$. pulmonarius, $P$. florida, $P$. citrinopileatus observed ranged from 64- $119 \mu \mathrm{g}$ catechol $\mathrm{g}^{-1} \mathrm{dw}$. The phenolic content in ethanolic extract of $P$. aureovillosus, $P$. sajor-caju, and $P$. florida were reported to range from $6.001-7.501 \mu \mathrm{g} / \mathrm{mg}$ (Loganathan et al., 2008). The research conducted by Dundar et al. (2013) revealed that the total phenolic compounds found in the ethanolic mycelia extracts of $P$. sajor-caju, $P$. florida, $P$. eryngii, and $P$. ostreatus ranged from $3.97-4.56 \mathrm{mg} / \mathrm{g}$ (dry weight). Debnath et al. (2017) examined ten Pleurotus species and reportedthat their total pheno content ranged between $0.50-4.33 \mathrm{mg} / \mathrm{g}$ with $P$. flabellatus and $P$. ostreatus have the lowest and highest total phenol contents respectively. The total flavonoid content assay is carried out to extract and estimate flavonoids, neoflavonoids and isoflavonoids or all together called as bioflavonoids. Previous studies had proved that flavonoids function as antioxidant by breaking the radical chains and converting them into more stable products in liver microsomal membranes, with the capacity to protect low density lipoprotein from being destroyed by macrophages and heavy metals which also play a central task of providing inherent fortification to counter oxidative stress and side effects by the presence of vitamins (Arbaayah and Kalsom, 2013). The total flavonoid was highest in P. pulmonarius with $12.2 \mu \mathrm{g} / \mathrm{mg}$ as reported by Adebayo et al. (2012b; 2014) and lowest in P. squarrosulus with $3.07 \mu \mathrm{g} / \mathrm{mg}$ (Pal et al., 2010). Arbaayah and Kalsom (2013) reported that the amount of total flavonoid content in $P$. pulmonarius, $P$. djamor var. djamor, $P$. ostreatus, and P. djamor var. roseus, from 3.02 to $14.88 \mathrm{mg} \mathrm{QE} / \mathrm{g}$ of dry weight of crude extract.

Oxygen Radical Absorbance Capacity (ORAC) and Lipid Peroxidation of Oyster Mushrooms

The oxygen radical absorbance capacity (ORAC) and lipid peroxidation of several oyster mushrooms have been reported as presented in Table 7. $P$ ostreatus had the highest ORAC of 8199.2 trolox equivalents while $P$. tuberregium had the lowest with 3316.0 trolox equivalent as reported by Adebayo $\boldsymbol{e}$ al. (2018). Extract of $P$. pulmonarius inhibited lipid peroxidation by $0.960 \mathrm{mg} / \mathrm{ml}$ with $P$. florida inhibiting with $0.320 \mathrm{mg} / \mathrm{ml}$ (Ajith and Janadhanan, 2007). Extracts of $P$. populinus inhibited lipid peroxidation by $26.64 \mu \mathrm{M}$ (Okafor et al., 2017). Lakshmi et al. (2004) presented ORAC values for $P$. florida, $P$. sajourcaju and $P$. rimosus extracts using spectrofluorimetric assay as follows; $(45.65 \pm$ 5.85), (43.94 \pm 8.66$)$, and $\operatorname{Pr}(30.59 \pm 1.59)$ as micromoles of Trolox equivalent per gram of fresh weight. From the above, it was clearly shown that $P$. florida recorded most potent scavenging peroxyl radicals in the ORAC assay.

\section{IN VIVO ASSAY OF FREE RADICAL SCAVENGING PROPERTY OF PLEUROTUS SPECIES}

The in vivoassay encompasses both enzymatic and non-enzymatic processes for scavenging or neutralizing free radicals (Govindan et al., 2016). In the enzymatic antioxidant assay, biomarker enzymes includes; catalase (CAT), glutathione peroxidase (GPx), superoxide dismutase (SOD), glutathione reductase(GR), glutathione $S$-transferase (GST), and ascorbate peroxidase (APx)(Govindan et al., 2016; Islam et al., 2019). The non-enzymatic assays mainly utilize Vitamin E ( $\alpha$-tocopherol), Glutathione (GSH), and vitamin C or ascorbic acid (Kim et al., 2010; Bhattacharyya et al., 2014; Islam et al., 2019) Enzymatic antioxidant activity of extracts of Pleurotus abalones, P. djamor, $P$. ostreatus, and $P$. eryngii var. tuoliensis increased the activity of SOD and inactivating superoxide radicals (Li et al., 2007; Anandhiet al., 2013; Zhanget al., 2015; Krishnamoorthy and Sankaran, 2016; Xuet al., 2017). CAT activity was increased by up regulating gene expression with subsequent prevention of toxicity resulting from the generation of hydrogen peroxide (Anandhiet al. 2013; Xuet al., 2017; Krishnamoorthy and Sankaran, 2016).

Table 6 Total Phenolic and Total Flavonoid Content

\begin{tabular}{lcccccc}
\hline Mushroom & Fermentation & Extractant & $\begin{array}{c}\text { Concentration } \\
(\mathbf{m g} / \mathbf{m L})\end{array}$ & $\begin{array}{c}\text { Total phenolic } \\
\text { content }\end{array}$ & $\begin{array}{c}\text { Total } \\
\text { flavonoid } \\
\text { content } \\
(\boldsymbol{\mu g} / \mathbf{m g})\end{array}$ & Reference \\
\hline P. pulmonarius LAU & Submerge & - & & & & \\
09 & & 1.0 & $\mathrm{NR}$ & 12.178 & Adebayo et al. (2012b) \\
& & 2.0 & $42.6 \mathrm{TAE}$ & $\mathrm{NR}$ & \\
\hline
\end{tabular}




\begin{tabular}{|c|c|c|c|c|c|c|}
\hline & Solid state & Methanol & $\begin{array}{l}1.0 \\
2.0 \\
5.0\end{array}$ & $\begin{array}{c}\mathrm{NR} \\
\text { 39.0 TAE } \\
\text { 43.0 TAE }\end{array}$ & $\begin{array}{l}12.2 \\
\text { NR } \\
\text { NR }\end{array}$ & Adebayo et al. (2014b) \\
\hline $\begin{array}{l}\text { P. pulmonarius CP- } \\
16\end{array}$ & Solid state & Hydro-alcohol & - & $0.080 \mathrm{GAE}$ & NR & Adebayo et al. (2018) \\
\hline $\begin{array}{l}\text { P. pulmonarius CP- } \\
799\end{array}$ & Solid state & Hydro-alcohol & - & $0.098 \mathrm{GAE}$ & NR & Adebayo et al. (2018) \\
\hline P. sapidus NE 07 & Solid state & Methanol & $\begin{array}{l}1.0 \\
2.0 \\
5.0\end{array}$ & $\begin{array}{c}\mathrm{NR} \\
30.0 \% \\
57.0 \%\end{array}$ & $\begin{array}{l}10.5 \\
\text { NR } \\
\text { NR }\end{array}$ & Adebayo et al. (2014b) \\
\hline $\begin{array}{l}\text { P. cornucopiae } \mathrm{NE} \\
02\end{array}$ & Solid state & Methanol & 1.0 & NR & 11.0 & Adebayo et al. (2014b) \\
\hline P. ostreatus LAU 10 & Solid state & Methanol & $\begin{array}{l}2.0 \\
5.0 \\
1.0 \\
2.0 \\
5.0\end{array}$ & $\begin{array}{c}34.0 \% \\
69.0 \% \\
\text { NR } \\
29.0 \% \\
43.0 \%\end{array}$ & $\begin{array}{l}\text { NR } \\
\text { NR } \\
10.4 \\
\text { NR } \\
\text { NR }\end{array}$ & Adebayo et al. (2014b) \\
\hline P. levis $\mathrm{CP}-30$ & Solid state & Hydro-alcohol & - & $0.057 \mathrm{GAE}$ & NR & Adebayo et al. (2014b) \\
\hline $\begin{array}{l}\text { P. pulmonarius LAU } \\
09\end{array}$ & Submerge & - & 1.0 & NR & 12.178 & Adebayo et al. (2014b) \\
\hline P. ostreatus CP-50 & Solid state & Hydro-alcohol & & $0.066 \mathrm{GAE}$ & NR & Adebayo et al. (2018) \\
\hline P. ostreatus CP- 800 & Solid state & Hydro-alcohol & & $0.129 \mathrm{GAE}$ & NR & Adebayo et al. (2018) \\
\hline P. ostreatus & Solid state & Methanol & & 17.6 GAE & NR & KongklaPoeaim (2016) \\
\hline $\begin{array}{l}\text { P. tuber-regium } \mathrm{CP}- \\
182\end{array}$ & Solid state & Hydro-alcohol & & $0.05 \mathrm{GAE}$ & NR & Adebayo et al. (2018) \\
\hline P. squarrosulus & Solid state & $\begin{array}{l}\text { Cold water } \\
\text { Hot water } \\
\text { Methanol }\end{array}$ & & $\begin{array}{l}0.08 \mathrm{GAE} \\
0.82 \mathrm{GAE} \\
0.18 \mathrm{GAE}\end{array}$ & $\begin{array}{l}3.62 \\
5.45 \\
3.07\end{array}$ & Pal et al. (2010) \\
\hline P. djamor & Solid state & $\begin{array}{l}\text { Acentonitrile } \\
\text { Hexane }\end{array}$ & & $\begin{array}{l}\text { 982.0 AAE } \\
\text { 35.0 AAE }\end{array}$ & $\begin{array}{l}\mathrm{NR} \\
\mathrm{NR}\end{array}$ & Rich et al. 2016 \\
\hline P. sajor-caju & Solid state & Methanol & & $15.75 \mathrm{GAE}$ & NR & $\begin{array}{l}\text { Kongkla and Poeaim } \\
\text { (2016) }\end{array}$ \\
\hline P. eиos & Solid state & Methanol & & $11.02 \mathrm{GAE}$ & NR & $\begin{array}{l}\text { Kongkla and Poeaim } \\
\text { (2016) }\end{array}$ \\
\hline P. eryngii & Solid state & Methanol & & $8.77 \mathrm{GAE}$ & NR & $\begin{array}{l}\text { Kongkla and Poeaim } \\
\text { (2016) }\end{array}$ \\
\hline P. cystidiosus & Solid state & Methanol & & $07.17 \mathrm{GAE}$ & NR & $\begin{array}{c}\text { Kongkla and Poeaim } \\
(2016)\end{array}$ \\
\hline
\end{tabular}

$\mathrm{EC}_{50}: 50 \%$ Effective Concentration; NR: Not Recorded; TAE: Tallic Acid Equivalent; GAE: Gallic Acid Equivalent; AAE: Ascorbic Acid Equivalent.

Table 7 Oxygen Radical Absorbance Capacity (ORAC) and Lipid Peroxidation Inhibition

\begin{tabular}{|c|c|c|c|c|}
\hline Mushroom & Extractant & $\begin{array}{l}\text { Oxygen radical } \\
\text { absorbance } \\
\text { capacity (TE) }\end{array}$ & $\begin{array}{l}\text { Lipid peroxidation } \\
\text { inhibition }\end{array}$ & Reference \\
\hline P. pulmonarius CP-16 & Hydro-alcohol & 6496.8 & NR & Adebayo et al. (2018) \\
\hline P. pulmonarius CP-799 & Hydro-alcohol & 4455.2 & NR & Adebayo et al.(2018) \\
\hline \multirow{2}{*}{$\begin{array}{l}\text { P. pulmonarius } \\
\text { Puts }\end{array}$} & Methanol & NR & $0.960 \mathrm{mg} / \mathrm{mL}$ & Ajith and Janardhanan (2007) \\
\hline & Hexane & NR & $28.86 \mu \mathrm{M}$ & Okafor et al. (2017) \\
\hline P. levis CP-30 & Hydro-alcohol & 5080.8 & NR & Adebayo et al. (2018) \\
\hline P. ostreatus $\mathrm{CP}-50$ & Hydro-alcohol & 8199.2 & NR & Adebayo et al. (2018) \\
\hline P. ostreatus CP-800 & Hydro-alcohol & 34646.0 & NR & Adebayo et al. (2018) \\
\hline P. ostreatus & Hexane & $\mathrm{NR}$ & $35.36 \mu \mathrm{M}$ & Okafor et al. (2017) \\
\hline P. tuber-regium $\mathrm{CP}-182$ & Hydro-alcohol & 3316.0 & NR & Adebayo et al. (2018) \\
\hline \multirow[t]{2}{*}{ P. florida } & Ethyl acetate & NR & $0.496 \mathrm{mg} / \mathrm{mL}$ & Ajith and Janardhanan (2007) \\
\hline & Methanol & NR & $0.320 \mathrm{mg} / \mathrm{mL}$ & \\
\hline P. sajor-caju & Hexane & NR & $32.26 \mu \mathrm{M}$ & Okafor et al. (2017) \\
\hline P. populinus & Hexane & NR & $26.64 \mu \mathrm{M}$ & Adebayo et al. (2018) \\
\hline
\end{tabular}

Metabolites from Pleurotus abalones, P. eryngii P. ostreatus, and P. djamor impacted positively on GPx activity by reducing hydrogen peroxide to water and scavenging endogenous peroxides species. It also decreased oxidative stress and prevent many complex diseases (Anandhiet al., 2013; Maet al., 2015; Zhang et al., 2015; Krishnamoorthy and Sankaran, 2016; Xu et al., 2017). Activity of GST improved with administration of $P$. ostreatus extract in rodent cell protected against free radicals induced cell damage (Jayakumar $\boldsymbol{e t}$ al., 2010; Thomas $\boldsymbol{e}$ al., 2014).P. ostreatus extract improved the function of APX which catalysed theconversion of hydrogen peroxide to water (Thomas et al., 2014). Nonenzymatic antioxidant assays using ascorbic acid components of $P$. ostreatus reduced ascorbate radicals and enhanced better antioxidant performance (Anandhiet al., 2013; Krishnamoorthy and Sankaran, 2016). Vitamin E or $\alpha$ tocopherol from $P$. ostreatus inhibited lipid peroxidation in cell membranes (Anandhiet al., 2013; Krishnamoorthy and Sankaran, 2016), and activity of GSH prevented oxidation of GSH and safeguard the redox enzymes (Jayakumar et al., 2010; Anandhiet al., 2013; Krishnamoorthy and Sankaran, 2016). A number of studies have reported the free radical scavenging property of oyster mushroom in experimental animals such as mice, rat, porcine etc. as summarized in Table 8. Remarkable improvement of thiobarbituric acid reactive substances was noted in porcine brains after administering fruiting body and mycelium of $P$. ostreatus and $P$. eryngii (Reis et al., 2012). In addition, both methanolic extract and powdery form of $P$. ostreatus were found effective in the treatment of streptozotocin induced diabetes in mice (Mircea et al., 2018). Likewise, enzyme assisted extraction of mycelia zinc polysaccharides of $P$. eryngii effectively treated hyperlipidemia in mice (Xu et al., 2017). Also, the fruiting body of $P$. ferulae induced an increased insulin level in streptozotocin induced diabetic rats (Wang et al., 2014), likewise pooled fruiting body of $P$. ostreatus and $P$ cystidiosus increased the utilization of glucose in Type 2 diabetic patients (Jayasuriya et al., 2015).

\section{HEALTH IMPLICATIONS OF Pleurotus SPECIES}

Pleurotus are exotic and healthy foods, which are low in calories and fat, high in chitin, vitamins, protein and mineral content (Mattila et al., 2002; Akindahunsi and Oyetayo, 2006). They also have elevated quantities of ornithine and $\gamma$-aminobutyric acid (GABA). GABA is a non-essential amino acid that acts as neurotransmitter while ornithine is one of the building blocks required for producing arginine (Jayakumar et al., 2006). Oyster mushrooms have been reported to be moderately high in polysaccharides and other antioxidant compounds (Tab 9). 
The multidirectional therapeutic and health-promoting effects of mushrooms of the genus Pleurotus result from the occurrence of secondary metabolites, that were extracted from both fruiting bodies and mycelia of oyster mushrooms (Morris et al., 2017). The bioactive compounds found in Pleurotus mushrooms can be distributed into low and high molecular weight compounds. Highmolecular weight bioactive components primarily are polysaccharides, including $\beta$-glucans, peptides and proteins while low-molecular weight bioactive compounds consist of terpenes, fatty acid esters and polyphenols (Patel and Goyal, 2012). In addition to free radical scavenging activities, oyster mushrooms are nutritional in nature and thus, could improve the general human health (Khan and Tonia, 2012; Kalac, 2013; Adebayo et al., 2014a).

The diverse health benefits of Pleurotus species are associated to their high nutritive value. For instance, Khatun et al. (2015) studied three Pleurotus species and reported that the lowest protein content was found in $P$. pulmonarius $(15-18 \% \mathrm{dw})$; trailed by $P$. citrinopileatus $(20-22 \% \mathrm{dw})$ and $P$. florida $(22-25 \% \mathrm{dw})$. Also, the cholesterol content of the three Pleurotus species studied ranged from 0.6 to $0.8 \% \mathrm{dw}$, therefore they are low in cholesterol, but rich in protein. In general, mushroom polysaccharides remain the most acknowledged and potent mushroom-derived bioactives. Precisely, natura mushroom polysaccharides, principally obtained from the culture media, fruiting body, and mycelia during mushroom cultivation, have received enormous attentions due to their richnessinbiopharmaceuticals and nutraceutical activities as well as anti-inflammatory, antioxidant, (Im et al., 2014), antihypertensive (Miyazawa et al., 2008), anti-aging (Zhang et al., 2014) and immune-boosting properties (Cui et al., 2015; Oloke and Adebayo, 2015). Oyster mushrooms are characteristically high in homopolysaccharides as reported by Lakhanpal and Thakur (2016). Free radicals are generated in pathological and/or norma cellular metabolism (Elmastas et al., 2007). Nonetheless, the unrestrained generation of oxygen-based free radicals is involved at the inception of some ailments, including rheumatoid arthritis, cancer, atherosclerosis, and cirrhosis, likewise in deteriorating processes connected with ageing (Gulcin $\boldsymbol{e t}$ al., 2008) Oxidative enzymes, including catalase (CAT), superoxide dismutase (SOD) and glutathione peroxidise (GSHPx)(Tadhani et al., 2007), or chemicals, includingtocopherol, carotenoids, ascorbic acid and polyphenolic compounds are accountable for protecting organisms against the damages caused by free radicals(Gulcin et al., 2008). The enzymatic antioxidant activity of P.pulmonarius, $P$. florida and $P$. citrinopileatus were evaluated and it was observed that catalase activities ranged from 1128- $2264 \mathrm{~g} /$ dry weight, peroxidase activities ranged from $14.14-18.76 \mathrm{~g}^{-1} \mathrm{~min}^{-1}$ and superoxide dismutase (SOD) activities ranged from 203.7- $345.7 \mathrm{~g} /$ dry weight(Khatun $\boldsymbol{e}$ al., 2015). Moreover, the presence of the diverse types of polysaccharides, alkaloids, flavonoids and other compounds in the oyster mushroom could be accountable for their high scavenging activities against the free radicals. This is believed to confer definitive defence power against the development of some diseases and general enhancement of human fitness. Reactive oxygen species (ROS), free radicals and oxidative stress are produced in the body through endogenous reactions, exposure to some physicochemical conditions and pathophysiological states (Devasagayam et al., 2004). These activities can result into changes in DNA, proteins, lipids and other biomolecules, consequently leading to disease development in the central nervous system, liver, heart, lungs, blood, kidneys, reproductive organs, skin and joints, which can later develop to systemic diseases and may spread to other multiple organs (Hepel and Andreescu, 2015). Antioxidants are capable of preventing and opposing the formation of reactive nitrogen and oxygen species (RNS/ROS) and oxidative stress, thereby preventing the damage or change in biomolecules in the body system (Halliwell, 1996). This is referred to as antioxidant defence mechanism, which aids in the maintenance of the overall health of an organism. Apart from the direct prevention of free radicals, Pleurotus species and their metabolites have been widely studied for various health benefits. According to Jayakumar et al. (2007), P.ostreatusextracts were reported to ease the hepatotoxic effect of description

Carbon tetrachloride $\left(\mathrm{CCl}_{4}\right)$ in rats and this notably protected some organs, including the heart, brain, and liver of matured rats against oxidative damage. $\mathbf{P k}$ et al. (2019) reported an in vitro cytotoxic test using MTT assay, that the polysaccharide of Pleurotus ostreatus (Jacq.) P. Kumm extracted at $10^{-3}$ to $10^{3}$ $\mu \mathrm{g} / \mathrm{ml}$ displayed time and dose-dependent inhibitory results on the mitotic division of EAC cells, with suppression above $90 \%$ at the highest concentration and at 72h. Also, Selegean et al. (2009) stated that both intracellular and extracellular proteins extract of $P$. ostreatus contained polysaccharides that have immunomodulating potentials. Percutaneous or oral administration of extract of $P$. eryngii in mice was reported to repress inflammation in delayedtype hypersensitivity allergic response (Jedinak et al., 2011). Moreover, $P$. ostreatus is one of the natural producers of lovastatin (including some higher fungi),

Table 8 In vivo Antioxidant Study of Oyster Mushroom

\begin{tabular}{|c|c|c|}
\hline Mushroom & Sample & Animal Used \\
\hline $\begin{array}{l}P . \text { ostreatus and } \\
P . \text { eryngii }\end{array}$ & $\begin{array}{l}\text { Fruiting Body and } \\
\text { Mycelium }\end{array}$ & Porcine (Susscrofa) Brains \\
\hline P. ostreatus & $\begin{array}{c}\text { Methanol Extract and } \\
\text { Powder }\end{array}$ & $\begin{array}{l}\text { Mice with streptozotocin- } \\
\text { induced diabetes } \\
(50 \mathrm{mg} / \mathrm{kg} \text {, intraperitoneal })\end{array}$ \\
\hline P. eryngii & $\begin{array}{l}\text { Enzymatic-extractable } \\
\text { mycelia zinc } \\
\text { polysaccharides }\end{array}$ & $\begin{array}{l}\text { Hyperlipidemic mice } \\
\text { induced by high-fat-high- } \\
\text { cholesterol emulsion } \\
\text { (HFHCM). }\end{array}$ \\
\hline P. ferulae & Fruiting Body & $\begin{array}{l}\text { Streptozotocin-induced } \\
\text { diabetic rats }\end{array}$ \\
\hline $\begin{array}{l}P . \text { ostreatus and } \\
P . \text { cystidiosus }\end{array}$ & Fruiting Body & Type 2 diabetic patients \\
\hline Table 9 Type & sactilatics & room (\% of fresh mus \\
\hline $\begin{array}{l}\text { Pleurotus } \\
\text { species }\end{array}$ & Type of Polysaccharides & References \\
\hline P. eryngii & Homopolysaccharides & $\begin{array}{l}\text { Lakhanpal and Thakur } \\
\text { (2016) }\end{array}$ \\
\hline P. florida & Homopolysaccharides & $\begin{array}{l}\text { Lakhanpal and Thakur } \\
\text { (2016) }\end{array}$ \\
\hline P. ostreatus & Homopolysaccharides & $\begin{array}{l}\text { Lakhanpal and Thakur } \\
\text { (2016) }\end{array}$ \\
\hline P. sajor-caju & Lovastatin polysaccharide & $\begin{array}{l}\text { Lakhanpal and Rana } \\
(2005)\end{array}$ \\
\hline
\end{tabular}

and it is primarily used for the prevention of cardiovascular diseases and for the treatment of dyslipidemia. Lovastatin, which is used as a drug for reducing the level of blood cholesterol, was created using $P$. ostreatus andappropriated for use in 1987 by the Federal Development Agency (Talkad et al., 2015).

In other related studies, $\alpha$-glucan obtained from $P$. ostreatus and proteins extracted from $P$. nebrodensis have also been reported for anticancer activities (Wu et al., 2011; Lv et al., 2009) while polysaccharides obtained from $P$. ostreatus have also been reported for its antitumor potentials (Tong et al., 2009).

Antioxidant Study
Lipid Peroxidation
Inhibition (TBARS
Assay)
SOD and Catalase
Enzyme Determination
SOD, GSH-Px, CAT, T-
AOC, MDA and LPO
Insulin and HbA1c
Levels

utilization of glucose by peripheral tissues

\begin{tabular}{cl} 
Result of the Study & Reference \\
\hline $\begin{array}{l}\text { Although, } P \text {. eryngii showed } \\
\text { lower TBARS assays, both } \\
\text { species showed significant }\end{array}$ & Reis et al. (2012)
\end{tabular}

species showed significant

improvement of the TBARS.
Improved the diabetic condition as detected via the SOD and

Catalase enzyme

The species showed potential of

preventing the HFHCM-induced

hyperlipidemia and nonalcoholic fatty liver

Insulin levels increased and

HbA1c levels decreased

Increased utilization of glucose

by peripheral tissues, reduced

glycogen synthase kinase with improved glycogen synthesis after 2 weeks
Mircea et al. (2018)

Xu et al. (2017)

Wang et al. (2015)

Jayasuriya et al.

(2015)

Also, heteroglycan obtained from $P$. ostreatus have been reported for immunomodulatory potentials (Devi et al., 2013). Khan et al. (2011) reported that lovastatin extracted from $P$. sajor-caju and $P$. florida possessed potentials to impact antihypercholesterolemic activities while the antihypertensive potentials of peptides obtained from $P$. cornucopiae have been reported (Jang et al., 2011). Hypoglycemic potentials of $\beta$-glucans from $P$. sajor-caju and polysaccharidepeptide from $P$. abalonus have been reported (Kanagasabapathy et al., 2012; Chen et al., 2015). Polysaccharides from $P$. ostreatoroseus and P. ostreatus were reported to possess anti-inflammatory activities (Gunawardena et al., 2014; Correa et al., 2015). Also, $\beta$-glucans extracted from $P$. ostreatus and $P$. sajorcajuhas been reported for anti-arthritic (Patel et al., 2012; Rovensky et al., 2011).

Furthermore, the antibacterial, antifungal and antiviral potentials of oyster mushrooms have also been aptly reported. The therapeutic potentials of Pleurotus have been exploitedfor combating simple and multiple drugresistantt isolates of $S$. aureus and $E$. coli according to report by Akyuz et al. (2010). The antibacterial and antifungal activity of Pleurotus species were reported to be dependent on the type of the extractant solvent used, for instance, acetone extract were less potent against Gram-negative bacteria compared to ether extract (Iwalokun et al., 2007). Acetone and ether extracts of Pleurotus 
mushrooms effectively inhibited the growth of $S$. cerevisiae, B. subtilis, and $E$. coli. $\beta$-glucans extracted from $P$. ostreatuswas reported to show antibacterial activities (Karaman et al., 2010; Mirunalini et al., 2012). Also, Suseem and Saral (2013) reported that fatty acids esters obtained from $P$. eous displayed antimicrobial activities. Moreover, Erjavec et al. (2012) reported that protein extracted from $P$. eryngii and $P$. ostreatus displayed antifungal activities while ergosterol extracted from $P$. cystidiosus also showed antifungal potentials (Menikpurage et al., 2009). Wang et al. (2007) showed that hot water extracts of $P$. pulmonarius and $P$. sajor-caju inhibited the activity of HIV-1 reverse transcriptase by SU2 molecule, with a molecular weight of $4.5 \mathrm{kDa}$. Also, lectin which was obtained from fresh sporophores of P. citrinopileatus reportedly hindered the activities of HIV-1 reverse transcriptase (Li et al., 2008) According to a report by $\mathbf{L v}$ et al. (2009), proteins obtained from P. nebrodensis were observed to possess antiviral activities, while polysaccharides and lectins extracted from $P$. abalones and $P$. citrinopileatus respectively were also reported to possess antiviral potentials (Wang et al., 2011; Hassan et al., 2015)

\section{CONCLUSION}

The current review has established different species of oyster mushrooms as good sources of natural antioxidant through in vitro assays (including DPPH, superoxide, nitric oxide, hydroxyl, ABTS scavenging and Oxygen radical absorbance capacity (ORAC) activities) and in vivo assays (enzymatic and nonenzymatic) using mice, rats and porcine brain. The potentials of antioxidants to oppose the formation of reactive oxygen and nitrogen species, prevent oxidative stress and scavenge free radicals which may be responsible for some human diseases have been established. However, future work should be focused on detailed structure-activity study of identified antioxidant molecules obtained from different Pleurotus spp. Moreover, the potential of oyster mushrooms as good antioxidants can positively influence their activities as natural immune boosters, anti-ageing and anti-cancer effects which can significantly improve human health. Hence, oyster mushroom, a portion of natural functional food could be recommended as a excellent source of antioxidants.

Acknowledgements: EAA is grateful to the Management of LAUTECH, Ogbomoso for making fund available for some aspects of this research work through Institution Based Research fundfrom TETFund (ARPUB14/TETFund/2017/09) under the project titled "Development of costeffective cultivation protocols for oyster mushrooms (Pleurotus species) in alleviating poverty, food and nutrition deficiency".

Mr Akinwale Temitope Ebenezer, an English Language expert is acknowledged for syntactic and grammatical errors correction.

Conflict of Interest: The authors declared that no conflict of interest exists in the submitted manuscript.

\section{REFERENCES}

Acharya, K., Khatua, S.,\& Ray, S. (2017). Quality assessment and antioxidant study of Pleurotus djamor (Rumph. ex Fr.) Boedijn. J Appl Pharmaceutical Sci., 7(6), 105-110.https://www.japsonline.com/admin/php/uploads/2299.

Adebayo, E.A., Martinez-Carrera, D., Morales, P., Sobal, M., Escudero, E., Meneses, E., Avila-Nava, A., Castillo, I., \& Bonilla, M. (2018). Comparative study of antioxidant and antibacterial properties of the edible mushrooms Pleurotus levis, P. ostreatus, P. pulmonarius and P. tuber-regium.Int J Food SciTechnol., 53(5), 1316-1330.https://doi.org/10.1111/ijfs.13712.

Adebayo, E.A., Oloke, J.K., Azeez, M.A., Omomowo, I.O.,\& Bora, T.C. (2014a) Assessment of the genetic diversity among ten genotypes of Pleurotus (Oyster mushroom) using nutrient and mineral compositions.Scientia Horticul., 166.5967.https://doi.org/10.1016/j.scienta.2013.12.010.

Adebayo, E.A., Oloke, J.K., Aina, D.A.,\& Bora, T.C. (2014b). Antioxidant and nutritional importance of some Pleurotus species.J Microbiol, Biotechnol and Food Sci., 3(4), 289-294. https://www.researchgate.net/publication/260020139.

Adebayo, E.A., Oloke, J.K., Ayandele, A.A., \&Adegunlola, C.O. (2012a) Phytochemical, antioxidant and antimicrobial assay of mushroom metabolite from Pleurotus pulmonarius-LAU 09 (JF736658).J MicrobiolBiotechnol Res.,2(2), 366-374.https://www.researchgate.net/publication/235992283.

Adebayo, E.A., Oloke, J.K., Majolagbe, O.N., Ajani, R.A.,\& Bora, T.C. (2012b) Antimicrobial and anti-inflammatory potential of polysaccharide from Pleurotus pulmonarius LAU 09.Afr J Microbiol Res., 6(13), 33153323.https://academicjournals.org/journal/AJMR/article-full-textpdf/934471523705.

Ajith, T.A.,\&Janardhanan, K.A. (2007). Indian Medicinal Mushrooms as a Source of Antioxidant and Antitumor Agents.J ClinBiochemNutr., 40,157-162. https://doi: $10.3164 /$ jcbn.40.157.

Akindahunsia, A.A.,\& Oyetayo, F.L. (2006). Nutrient and antinutrient distribution of edible mushroom, Pleurotus tuber-regium (fries) singer. LWT Food Sci Technol., 39(5), 548-553. DOI: 10.1016/j.lwt.2005.04.005.

Akyuz, M., Onganer, A.N., Erecevit, P.,\& Kirbag, S. (2010). Antimicrobial activity of some edible mushrooms in the eastern and southeast Anatolia region

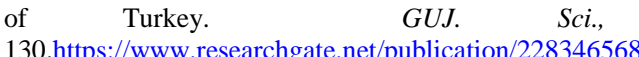

23(2),

$125-$

Akyuz, M.,\&Kirbag, S. (2010).Nutritive value of wild edible and cultured mushrooms.Turk J Biol., 34, 97-102. http://dx.doi:10.3906/biy-0805-17.

Anandhi, R., Annadurai, T., Anitha, T.S., Muralidharan, A.R., Najmunnisha, K Nachiappan, V., Thomas, P.A.,\& Geraldine, P. (2013). Antihypercholesterolemic and antioxidative effects of an extract of the oyster mushroom, Pleurotusostreatus, and its major constituent, chrysin, in Triton WR-1339 induced hypercholesterolemic rats.J PhysiolBiochem., 69(2), 313 23.https://www.ncbi.nlm.nih.gov/pubmed/23104078.

Arbaayah, H.H.,\& Kalsom, Y.U. (2013). Antioxidant properties in the oyster mushrooms (Pleurotus spp.) and split gill mushroom (Schizophyllumcommune) ethanolic extracts. Mycosph.,4(4),

673.https://www.researchgate.net/publication/269953071.

Bamigboye, C.O., Oloke, J.K.,\&Dames, J.F. (2019a). Development of high yielding strain of Pleurotus tuber-regium: fructification, nutritional and phylogenetic studies. $J$ Food Sci Tech., 56(8), 3597 3608.https://link.springer.com/article/10.1007/s13197-019-03786-7.

Bamigboye, C.O., Oloke, J.K., Burton, M., Dames, J.F.,\& Lateef, A (2019b).Optimization of the process for producing biomass and exopolysaccharide from the King Tuber Oyster Mushroom, Pleurotus tuberregium (Agaricomycetes) for Biotechnological Applications.Int J Med Mushr., 21(4), 311-322.https://www.ncbi.nlm.nih.gov/pubmed/31002627.

Bamigboye, C.O., Oloke, J.K.,\& Dames, J.F. (2016a). "Biological activity of extracellular and intracellular polysaccharides from Pleurotus tuber-regium hybrid and mutant strains."J Food Nutr Res., 4(7), 422-428. http://doi: 10.12691/jfnr-4-7-2.

Bamigboye, C.O.,\& Oloke, J.K. (2016b). Ameliorative effect of Lentinus squarrosulus mycomeat against Pseudomonas aeruginosa infection using albino rat as animal model.Afr $J$ Biotech., 15(26),1383-1390.DOI: 10.5897/AJB2014.14353.

Bamigboye, C.O., Oloke, J.K., Adebayo, E.A., Majolagbe, O.N., Ayandiran, T.A.,\&Adegunlola, E.O. (2013). Mycomeat production through the solid statefermentation of soymilk waste by Lentinus subnudus. J Nat Sci Res.,3,8893.https://www.researchgate.net/publication/259762225.

Barbosa, J. R., dos Santos Freitas, M. M., da Silva Martinsc, L. H., de Carvalho Junior, R. N. (2020). Polysaccharides of mushroom Pleurotus spp.: New extraction techniques, biological activities and development of new technologies. Carbohydr polym, 229, 115550

Barros, L., Venturini, B.A., Baptista, P., Estevinho, L.M.,\& Ferreira, I.C.F.R (2008). Chemical composition and biological properties of Portuguese wild mushrooms: a comprehensive study. J Agric Food Chem., 56(10),38563862.https://www.researchgate.net/publication/5416469.

Bhattacharyya, A., Chattopadhyay, R., Mitra, S.,\& Crowe, S.E. (2014). Oxidative stress: an essential factor in the pathogenesis of gastrointestinal mucosal diseases.
Physiol
Rev.,
94(2),

54.https://www.ncbi.nlm.nih.gov/pmc/articles/PMC4044300/.

Caglarırmak, N. (2007). The nutrients of exotic mushrooms (LentinulaedodesandPleurotusspecies) and an estimated approach to the volatile compounds.Food Chem..105, http://dx.doi.org/10.1016/j.foodchem.2007.02.021

Carneiro,A.A.J., Ferreira, I.C.F.R., Duenas, M., Barros, L., da Silva, R.,Gomes, E., \& Santos-Buelga, C. (2013). "Chemical composition and antioxidant activity of dried powder formulations of AgaricusblazeiandLentinusedodes,' Food Chem.,138 (4),

2173.https://www.ncbi.nlm.nih.gov/pubmed/23497872.

Chang, S.T.,\& Buswell, J.A. (2003). Medicinal mushrooms - as prominent source of nutriceuticals for the 21st century. Curr Topics in Nutraceutical Res., 1, 257-280.https://www.researchgate.net/publication/306178009.

Chen, R.-R., Liu, Z.-K., Liu,F.,\& Ng, T.B.(2015). Antihyperglycemic mechanism of an aceteoside polymer from rose flowers and a polysaccharideprotein complex from abalone mushroom.Nat Prod Res., 29, 558 561.https://www.researchgate.net/publication/265475257.

Cohen, R., Persky, L.,\& Hadar, Y. (2002). Biotechnological applications and potential of wood-degrading mushrooms of the genus Pleurotus. ApplMicrobiolBiotechnol., 58, 582-594. http://dx.doi.org/10.1007/s00253-0020930-y.

Correa, R.G.G., Brugnari, T., Bracht, A., Peralta, R.M.,\&Ferreira, I.C.F.R (2016). Biotechnological, nutritional and therapeutic uses of Pleurotus spp (Oyster mushrooms) related with its chemical composition: A review on the past decade findings. Trends Food Sci. Technol.,50, 103 117.https://doi.org/10.1016/j.tifs.2016.01.012.

Cui, H.Y., Wang, C.L., Wang, Y.R., Li, Z.J., Chen, M.H.,\& Li, F.J. (2015) Pleurotusnebrodensis polysaccharide (PN-S) enhances the immunity of immune suppressed mice. Chin J Natural Med., 13(10), 0760-0766. doi: 10.1016/S18755364(15)30076-5

Dandapat, S.,\&Sinha, M.P. (2015).Antioxidant and Anti-Inflammatory Activityof Pleurotus tuber-regium (Rumph. ex Fr.) Singer.AdvBiol Res.,9 (3), 140-145. https://www.academia.edu/23912125/. 
Debnath, S., Upadhyay, R.C., Das, P.,\& Saha,A.K. (2017). Antioxidant activities of methanolic extracts from ten Pleurotus species.Int Res J Pharm, 8(3), 4449.https://www.researchgate.net/publication/314983245.

Devasagayam, T.P.A., Tilak, J.C., Boloor, K.K., Sane, K.S., Ghaskadbi, S.S.,\& Lele, R.D. (2004). Free Radicals and Antioxidants in Human Health: Current $\begin{array}{lllll}\text { Status and Future } & \text { Prospects. }\end{array}$ 804.https://www.ncbi.nlm.nih.gov/pubmed/15909857.

Devi, K.S.P., Roy, B., Patra, P., Sahoo, B., Islam, S.S.,\& Maiti,T.K.(2013) Characterization and lectin microarray of an immunomodulatory heteroglycan from Pleurotus ostreatusmycelia. CarbohydrPolym., 94(2), 857 865.https://www.ncbi.nlm.nih.gov/pubmed/23544643.

Dubost, N.J., Ou, B.,\& Beelman, R.B. (2007). Quantification of polyphenols and ergothioneine in cultivated mushrooms and correlation to total antioxidant capacity.Food Chem.. 105 ,

735.https://doi.org/10.1016/j.foodchem.2007.01.030.

Duh, P.D., Tu, Y.Y.,\& Yen, G.C. (1999). Antioxidant activity of water extract of Harng Jyur (Chrysanthemummorifolium Ramat). LWT-Food Sci Technol., 32(5), 269-277.https://doi.org/10.1006/fstl.1999.0548.

Dundar, A., Okumus, V., Ozdemir, S.,\& Yildiz, A. (2013). Antioxidan properties of cultured mycelia from four Pleurotus species produced in submerged medium. Int $J$ Food Prop.,16(5), 1105 1116.https://www.tandfonline.com/doi/full/10.1080/10942912.2011.576793.

Elmastas, M., Isildak, O., Turkekul, I.,\& Temur, N. (2007). Determination of antioxidant activity and antioxidant compounds in wild edible mushrooms. $J$ 345.https://doi.org/10.1016/j.jfca.2006.07.003.

Erjavec, J., Kos, J., Ravnikar, M., Dreo, T.,\& Sabotic, J.(2012). Proteins of higher fungi - from forest to application.TrendsBiotechnol., 30, 259 273.https://doi.org/10.1016/j.tibtech.2012.01.004.

Fereshteh, A., Møller, S.G.,Hashemzadeh-Chaleshtori, M., Bidkhori, G.,\& Mohammad-Saeid, J. (2017). Molecular Mechanisms behind Free Radica Scavengers Function against Oxidative Stress.Antioxid.,6(3), 51.https://www.mdpi.com/2076-3921/6/3/51.

Gambato, G., Todescato, K., Pavao, E.M., Scortegagna, A., Fontana, R.C., Salvador, M.,\& Camassola, M. (2016). Evaluation of productivity and antioxidant profile of solidstate cultivated macrofungi Pleurotusalbidus and Pycnoporussanguineus. BioresTechnol.

20 ,

207:46-51

https://doi.org/10.1016/j.biortech.2016.01.121.

Govindan, S., Johnson, E.E., Christopher, J., Shanmugam, J., Thirumalairaj, V.,\& Gopalan, J. (2016). Antioxidant and anti-aging activities of polysaccharides from Calocybeindica var. APK2.Exp ToxicolPathol., 68(6), 32934.https://www.ncbi.nlm.nih.gov/pubmed/27174669.

Gulcin, I. (2012). "Antioxidant activity of food constituents: an overview," Archives of $\quad$ Toxicol., $\quad 86(3)$,

391.https://www.ncbi.nlm.nih.gov/pubmed/22102161.

Gulcin, I., Oktay, M., Kirecci, E.,\& Kufrevioglu, O.I. (2003).Screening of antioxidant and antimicrobial activities of anise (PimpinellaanisumL.) seed extracts.Food Chem., 83, 371-382.https://doi.org/10.1016/S0308$\underline{8146(03) 00098-0}$

Gulcin, I., Tel, A.Z.,\& Kirecci, E. (2008).Antioxidant, antimicrobial, antifungal, and antiradical activities of Cyclotrichium Niveum(BOISS.)Manden and Scheng.Int $J$ of Food $\quad$ Prop.,11, 450 471.https://doi.org/10.1080/10942910701567364.

Gulcin-Buyukokuroglu,M.E., Oktay, M.,\& Kufrevioglu, O. (2003).Antioxidant and analgesic activities of turpentine of PinusnigraArn.subsp.pallsiana (Lamb.) Holmboe.J. Ethnophar. 86 $51-$

58.https://www.ncbi.nlm.nih.gov/pubmed/12686441.

Gunawardena, D., Bennett, L., Shanmugan, K., King, K., Wiliams, R., Zabarasa D., Head, R., Ooi, L., Gyengesi, E.,\&Münch, G. (2014). Antiinflammatory effects of five commercially available mushroom species determined in

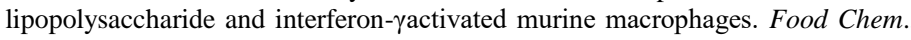
148, 92-96.https://www.ncbi.nlm.nih.gov/pubmed/24262531.

Halliwell, B. (1996). Antioxidants in human health and diseases. Anna Rev Nutr., 16, 33-50.https://www.ncbi.nlm.nih.gov/pubmed/8839918.

Halliwell, B.,\& Gutteridge, J.M.C. (2003).Free Radicals in Biology and Medicine; Oxford University Press, Oxford, UK.

Hamzah, R.U., Jigam, A.A., Makun,H.M.,\&Egwim, E.C. (2014). Phytochemical screening and antioxidant activity of methanolic extract of selected wild edible Nigerian mushrooms. Asian Pac J Trop Dis.,4 (Suppl 1), S153 S157.http://dx.doi.org/10.1016/S2222-1808(14)60431-X.

Hassan, M., Rouf, R., Tiralongo, E., May, T.,\& Tiralongo, J.(2015). Mushroom lectins: specificity, structure and bioactivity relevant to human disease. Int J Mol Sci., 16, 7802-7838.https://www.ncbi.nlm.nih.gov/pubmed/25856678.

Hepel, M.,\& Andreescu, S. (2015). Oxidative Stress and Human Health.Oxidative Stress: Diagnostics, Prevention, and Therapy Volume 2, ACS Symposium Series; American Chemical Society: Washington, DC., Pp, 1-33. https://pubs.acs.org/doi/abs/10.1021/bk-2015-1200.ch001.

Idu, M., Osemwegie, O., Timothy, O.,\& Onyibe, H.I. (2007). A survey of plants used in traditional healthcare by Waja tribe Bauchi State, Nigeria. Plant Arch., 7(2), 535- 538.https://www.researchgate.net/publication/295727073.
Im, K.H., Nguyen, T.K., Shin, D.B., Lee, K.R.,\& Lee, T.S. (2014). Appraisal of antioxidant and anti-inflammatory activities of various extracts from the fruiting bodies of Pleurotusflorida. $\quad$ Mol., $\quad 19(3), \quad 3310$ 3326.DOI:10.3390/molecules19033310.

Ishikawa, N.K., Kasuya, M.C.M., Vanetti, M.C.D. (2001). Antibacterial activity of Lentinulaedodesgrown in liquid medium.Braz. J. Microbiol. 32: 206-210. http://dx.doi.org/10.1590/S1517-83822001000300008.

Islam, T., Ganesan, K., \&Xu, B. (2019).New Insight into Mycochemical Profiles and

Antioxidant Potential of Edible and Medicinal Mushrooms: A Review. Int J Med Mushrooms, 21(3), 237-251. DOI:10.1615/IntJMedMushrooms.2019030079.

Iwalokun, B.A., Usen, U.A., Otunba, A.A.,\& Olukoya, D.K. (2007) Comparative phytochemical evaluation, antimicrobial and antioxidant properties of Pleurotusostreatus. Afri. J. Biotechnol., 6, 1732-1739. DOI 10.5829/idosi.wifpb.2012.3.1.303.

Jang, J. H., Jeong, S.C., Kim,J.H., Lee, Y.H., Ju, Y.C.,\& Lee, J.S., (2011) Characterization of a new antihypertensive angiotensin 1-converting enzyme inhibitory peptide from Pleurotus cornucopiae.Food Chem., 127, 412418.https://www.ncbi.nlm.nih.gov/pubmed/23140680.

Jayakumar ,T., Ramesh, E.\& Geraldine, P. (2006). Antioxidant activity of the oyster mushroom, Pleurotusostreatus, on CCl4-induced liver injury in rats Food Chem Toxicol., 44, 1989-1996. DOI: 10.1016/i.fct.2011.09.026.

Jayakumar, T., Thomas, P.A.,\& Geraldine, P. (2007). Protective effect of an extract of the oyster mushroom, Pleurotusostreatus, on antioxidants of major organs of aged rats. Exp Gerontol., 42, 183-91. DOI: 10.3736/jcim20100808. Jayakumar, T., Thomas, P.A.,\& Geraldine, B.P. (2009). In-vitro antioxidan activities of an ethanolicextract of the oyster mushroom, Pleurotus ostreatus Innovative Food Sci Emerging Technol.,10, 228 234.https://doi.org/10.1016/j.ifset.2008.07.002

Jayakumar ,T., Thomas, P.A., Ramesh, E.\&\& Geraldine, P. (2010). An extract of the Pleurotusostreatus mushroom bolsters the glutathione redox system in various organs of aged rats. J Med Food., 13(4): 771778.https://www.ncbi.nlm.nih.gov/pubmed/20673055.

Jayakumar, T., Thomas, P.A., Sheu,J.R.,\&Geraldine, P. (2011). In vitro and in vivo antioxidant effects of the oyster mushroom Pleurotus ostreatus. Food Res Int., 44, 851-861.https://www.researchgate.net/publication/251629317.

Jayasuriya,W.J.,Wanigatunge, C.A., Fernando, G.H., Abeytunga, D.T.,\& Suresh, T.S. (2015). Hypoglycaemic activity of culinary Pleurotusostreatus and $P$. cystidiosus mushrooms in healthy volunteers and type 2 diabetic patients on diet control and the possible mechanisms of action.Phytother.Res., 29(2), 303 309.doi: 10.1002/ptr.5255.

Jedinak, A., Dudhgaonkar, S., Wu, Q.L., Simon, J.,\& Sliva, D. (2011). Antiinflammatory activity of edible oyster mushroom is mediated through the inhibition of NF-kB and AP-1 signaling. Nutri J., 10, 52-62. DOI 10.1186/1475-2891-10-52.

Jeena, G.S., Punatha, H., Prakash, O., Chandra, M.,\& Kushwaha, K.P.S. (2016) Study on in vitro antioxidant potential of some cultivated Pleurotus species (Oyster mushroom). Ind J Natural Products and Res (IJNPR)[Formerly Natural Product Radiance (NPR)]., 5(1),

61.https://www.researchgate.net/publication/267035869.

Jong, S.C. (2002). Fungi cell wall glycans. Chp. 6.pp. 159-177, In; Polysaccharides II, Polysaccharides from Eukaryotes, Vol. 6, Biopolymers, Eds, S. DeBaets, E.J. Vandamme and A. Steinbuchel, Wiley-VCH, Weinheim.https://www.amazon.com/Polysaccharides-II-EukaryotesBiopolymers-Vol/dp/3527302271.

Kalac, P. (2013). A review of chemical composition and nutritional value of wild-growing and cultivated mushrooms.J Sci, Food Agric., 93(2), 209-218. doi $10.1002 /$ jsfa. 5960

Kalyoncu, F., Oskay, M., Sağlam, H., Erdoğan, T.F.,\& Tamer, A.Ü. (2010) Antimicrobial and antioxidant activities of mycelia of 10 wild mushroom species. $J$ of med.Food., 13(2),

419.https://www.researchgate.net/publication/41654980.

Lakshmi, B., Tilak, J.C., Adhikari, S., Devasagayam, T.P.A., \& Janardhanan, K.K. (2004). Evaluation of Antioxidant Activity of Selected Indian Mushrooms Pharma. Biol., 42 (3), 179-185. https://doi.org/10.1080/13880200490514023,

Kanagasabapathy, G., Kuppusamy, U.R., Malek, S.N.A., Abdulla, M.A., Chua K. H.,\& Sabaratnam, V.(2012). Glucan-rich polysaccharides from Pleurotussajor-caju(Fr.) Singer prevents glucose intolerance, insulin resistance and inflammation in C57BL/6J mice fed a high-fat diet. BMC Complement.Altern.Med.

261.https://www.ncbi.nlm.nih.gov/pmc/articles/PMC3553037/

Karaman, M., Jovin, E., Malbasa, R., Matavuly, M.,\& Popovic, M.(2010) Medicinal and edible lignicolous fungi as natural source of antioxidative and antibacterial agents. Phytother. Res., 24, 1473 1481.https://www.ncbi.nlm.nih.gov/pubmed/20878697.

Khan, M.A., Rahman, M.M., Tania, M., Uddin, M.N., \& Ahmed, S.(2011) Pleurotussajor-caju and Pleurotus florida mushrooms improve some extent of the antioxidant systems in the liver of hypercholesterolemic rats. Open Nutraceuticals J., 4, 20-24.https://www.researchgate.net/publication/221709832. 
Khan, M.A.,\& Tania, M. (2012). Nutritional and Medicinal Importance of Pleurotusmushrooms: An Overview. Food Rev Inter., 28(3), 313-329. http://dx.doi.org/10.1080/87559129.2011.637267.

Khan, M.A., Tania, M., Zhang, D.,\&Chen, H. (2010). Antioxidant enzymes and cancer.Chin J Cancer Res., 22, 87-92. http://dx.doi.org/10.1007/s11670-010 0087-7.

Khatun, S., Islam, A., Cakilcioglu, U., Guler, P.,\& Chatterjee, N.C. (2015) Nutritional qualities and antioxidant activity of three edible oyster mushrooms (Pleurotus spp.).NJAS-Wageningen Journal of Life Sci.,72, 15.https://doi.org/10.1016/i.njas.2012.03.003.

Kim, J.I., Kang, M.J., Im, J., Seo, Y.J., Lee, Y.M., \&Song, J.H. (2010). Effect of king oyster mushroom (Pleurotuseryngii) on insulin resistance and dyslipidemia in $\mathrm{db} / \mathrm{db} \quad$ mice.FoodSciBiotechnol.,19,

239-242.

http://dx.doi.org/10.1007/s10068-010-0033-y.

Kolayli, S., Sahin, H., Aliyazicioglu, R.,\& Sesli, E. (2012). Phenolic components and antioxidant activity of three edible wild mushrooms from Trabzon Turkey.Chem Nat Comp.,48(1),

140.https://link.springer.com/article/10.1007/s10600-012-0182-8.

Kongkla, K.,\& Poeaim, S. (2016). Total phenolic content and antioxidant activity of crude methanolic extract from five Pleurotusspecies. IntJAgric Technol. 12(7.1), 1455-1462.http://www.ijat-aatsea.com/pdf/v12_n7.

Krinsky, N.I. (2001). Carotenoids as antioxidants.Nutr., 17, 815-817. https://www.researchgate.net/publication/9035299.

Krishnamoorthy, D.,\& Sankaran, M. (2016). Modulatory effect of Pleurotusostreatuson oxidant/antioxidant status in 7,12-dimethylbenz(a) anthracene induced mammary carcinoma in experimental rats: a dose-response study. $J$ Cancer Res Ther., 12(1), 386-394. https://www.ncbi.nlm.nih.gov/pubmed/27072268.

Kurutas, E.B. (2016). The importance of antioxidants which playthe role in cellular response againstoxidative/nitrosativestress: current state. Nutr J., 15(1), 71. DOI 10.1186/s12937-016-0186-5.

Lai., L.S., Chou, S.T., Chao, W.W. (2001). Studies on the antioxidative activities of Hsian-tsao (Mesonaprocumbens Hemsl) leaf gum. JAgric food Chem.,49(2), 963-968.https://pubs.acs.org/doi/10.1021/jf001146k.

Lakhanpal, T.N.,\& Rana, M. (2005). Medicinal and nutraceutical genetic resources of mushrooms.Plant Genet Resour., 3, 288-303.DOI: 10.1079/PGR200581.

Lakhanpal, T.N., \&Thakur, I.S. (2016).Biodiversity of wild edible, mycorrhizal and nutraceutically important mushrooms, in: S. Sharma (Ed.), Mushrooms in India (Diversity, Improvement, Cultivation, Medicinal Uses and Value Addition for Rural Development).P. 262.

Lavi, I., Friesem, D., Geresh, S., Hadar, Y.,\&Schwartz, B. (2006). "An aqueous polysaccharide extract from the edible mushroom Pleurotusostreatusinduces anti-proliferative and pro-apoptotic effects on HT-29 colon cancer cells".Cancer Lett., 244 (1), 61-70.https://www.researchgate.net/publication/7359432.

Lee, Y.L., Huang, G.W., Liang, Z.C.,\&Mau, J.L. (2007). Antioxidant properties of three extracts from Pleurotus citrinopileatus. LWT-Food Sci Technol., 40(5), 823-833.https://doi.org/10.1016/j.lwt.2006.04.002.

Li, L., Ng, T.B., Song, M., Yuan, F., Liu, Z.K., Wang, C.L., Jiang, Y., Fu, M.,\& Liu, F. (2007). A polysaccharide-peptide complex from abalone mushroom (Pleurotus abalonus) fruiting bodies increases activities and gene expression of antioxidant enzymes and reduceslipid peroxidation in senescence-accelerated $\begin{array}{llll}\text { mice. } & \text { Appl. } & \text { Microbiol. } & \text { Biotechnol., }\end{array}$ 9.https://www.ncbi.nlm.nih.gov/pubmed/17347821.

Li, Y.R., Liu, Q.H., Wang, H.X.,\&Ng, T.B. (2008). A novel lectin with potent antitumor, mitogenic and HIV-1 reverse transcriptase inhibitory activities from the edible mushroom Pleurotuscitrinopileatus. Biochimica et Biophysica Acta (BBA) - Gen Subj., 1780(1), 51-57. DOI: 10.1016/j.bbagen.2007.09.004

Lo, S.H. (2005). Quality evaluation of Agaricus bisporus, Pleurotus eryngii, Pleurotus ferulae and Pleurotus ostreatus and their antioxidant properties during postharvest storage. Taichung (Taiwan): National Chung-Hsing University.

Loganathan, J.K., Ramalingam, S., Venkatasubbu, V.K.,\& Venkatesan, K (2008). Studies on the phytochemical, antioxidant and antimicrobial properties of three indigenous Pleurotus species.J Mol Biol. Biotechnol., 1, 2029.https://www.researchgate.net/publication/237312364.

Lobo, V., Patil, A., Phatak, A.,\& Chandra, N. (2010). Free radicals, antioxidants and functional foods: Impact on human health. Pharm Rev., 4(8), 118 127.https://www.ncbi.nlm.nih.gov/pmc/articles/PMC3249911/.

Lv, H., Kong, Y., Yao, Q., Zhang, B., Leng, F. W., Bian, H. J., Balzarini, J., Van Damme, E.,\&Bao, J.K.(2009). Nebrodeolysin, a novel hemolytic protein from mushroom Pleurotus nebrodensis with apoptosis-inducing and anti-HIV-1 effects.Phytomed., 16, 198-205.https://www.ncbi.nlm.nih.gov/pubmed/18722099. Ma, Z., Zhang, C., Gao, X., Cui, F., Zhang, J., Jia, M., Jia, S.,\& Jia, L. (2015) Enzymatic and acidic degradation effect on intracellular polysaccharide of Flammulinavelutipes SF-08.Int $J \quad$ BiolMacromol., $\quad 73, \quad 236$ 44.https://www.ncbi.nlm.nih.gov/pubmed/25481282.

Mattila, P., Salo-Väänänen, P., Könkö, K., Aro, H.,\&Jalava, T. (2002) .Basic composition and amino acid contents of mushrooms cultivated in Finland. $J$. Agr. Food Chem., 50, 6419-6422. https://www.ncbi.nlm.nih.gov/pubmed/12381127.
Mau, J.L., Chao, G.R.,\&Wu, K.T. (2001). Antioxidant properties of methanol extracts from several ear mushrooms. J Agric Food Chem., 49, 54615467.https://www.ncbi.nlm.nih.gov/pubmed/11714344.

Meng, H.L.,\& Luo, L. (2016). Antitumor polysaccharides from mushrooms: A review on the structural characteristics, antitumor mechanisms and immunomodulating activities. Carbohydr Res., 424(7), 30-41. doi: 10.1016/j.carres.2016.02.008.

Menikpurage, I.P., Abeytunga, D.T., Jacobsen, N.E., \& Wijesundara, R.L. (2009). An oxidize ergosterol from Pleurotuscystidiosus active against anthracnose causing Colletotrichum gloeosporioides. Mycopathol., 167, 155162.https://www.ncbi.nlm.nih.gov/pubmed/18825508.

Mircea, C., Cioanca,O.,Bild,V.,Iancu, C., Stan, C.,\& Hăncianu, M. (2018). In vivo antioxidant properties of some mushroom extracts in experimentally induced diabetes. Farmacia., $66(2)$,

257

261.https://www.researchgate.net/publication/324981577.

Mirunalini, S., Arulmozhi, V., Deepalakshmi, K.,\& Krishnaveni, M.(2012) Intracellular biosynthesis and antibacterial activity of silver nanoparticles using edible mushrooms.Not Sic. Biol., 4 (4), 55 61.https://notulaebiologicae.ro/index.php/nsb/article/view/8051.

Miyazawa, N., Okazaki, M.,\& Ohga, S. (2008). Antihypertensive effect of Pleurotusnebrodensis in spontaneously hypertensive rats.J Oleo Sci., 57(12) 675-681.https://doi.org/10.5650/jos.57.675.

Morris, H.J., Beltran, Y., Llaurado, G., Batista, P.L., Perraud-Gaime, I., Garcia, N.,Moukha, S., Bermúdez, R.C., Cos, P., Hernández, E.,\&Diez, J.C.(2017) Mycelia from Pleurotussp. (oyster mushroom): a new wave of antimicrobials, anticancer and antioxidant bio ingredients. Int J Phytocosm Nat Ingred., 2, 14 https://ijpni.org/Abstract/IJPNI 112 20161228163011.

Murcia, A.M., Martinez-Tome, M., Jimenez, A.M., Vera, A., Honrubia M.,\&Parras, P. (2002). Antioxidant activity of edible fungi (truffles and mushrooms): Losses during industrial processing.J Food Prot., 65 , 1614-1622.https://www.researchgate.net/publication/11079334.

Nardini, M.,\&Ghiselli, A. (2004). Determination of free and fond phenolic acids in beer.Food Chem., 84, 137-143.https://europepmc.org/article/agr/ind44639580. Nau, W.M. (1998). A fluorescent probe for antioxidants.J American ChemSoc., 120, 12614-12618. http://dx.doi.org/10.1021/ja981453v.

Okafor, D.C., Onuegbu, N.C., Odimegwu, N.E., Ibeabuchi, J.C., Njoku, N.E., Agunwa, I.M., Ofoedu, C.E.,\&Njoku, C.C. (2017). Antioxidant and Antimicrobial Activities of Oyster Mushroom.American J Food Sci Technol., 5(2), 64-69. doi: 10.12691/ajfst-5-2-6.

Oloke, J.K.,\& Adebayo, E.A. (2015). Effectiveness of immunotherapies from oyster mushroom (Pleurotus species) in the management of immune compromised patients.Int J Imm., 3(2), 8-20. doi: 10.11648/j.iji.s.2015030201.12. Osemwegie, O.O., Okhuoya, J.A., Akpaja, E.O., Oghenekaro,A.O.,\&Ihayere, C.A. (2010). Nigeria Mushrooms: Underutilized Non- Wood Forest Resources. $J$ ApplSciEnv Man., 14(1), 43-54.http://dx.doi.org/10.4314/jasem.v14i1.56488.

Pal, J., Ganguly, S., Tahsin, S.,\& Acharya, K. (2010). In vitro free radical scavenging activity of wild edible mushroom, Pleurotussquarrosulus (Mont.) Singer.Indian $J \quad J x p \quad$ Biol.,48(12), 1218.https://www.ncbi.nlm.nih.gov/pubmed/21250603.

Patel, S., Goyal, A.(2012). Recent developments in mushroom as anti-cancer therapeutics: a review. 3 Biotech., $2, \quad 1$ 15.https://www.ncbi.nlm.nih.gov/pubmed/22582152.

Patel, Y., Naraian, R.,\& Singh, V.K. (2012). Medicinal properties of Pleurotus species (oyster mushroom): a review. World J Fungal and Plant Biol., 3(1), 1 12.https://www.researchgate.net/publication/296862505.

Patil, S.S., Ahmed, S.A., Telang, S.M., \& Baig, M.M.V. (2010). The nutritiona value of Pleurotusostreatus(jacq. fr.) Kumm cultivated on differen lignocellulosicagrowastes. Inn Romanian Food Biotechnol., 7, 66-70. https://www.researchgate.net/publication/269819452.

Pham-Huy, L.A., He, H.,\& Pham-Huy, C. (2008). Free Radicals, Antioxidants in Disease and Health. Int J Biomed Sci., $4 \quad$ (2), 89 96.https://www.ncbi.nlm.nih.gov/pubmed/23675073.

Phaniendra, A.,Jestadi, D.B.,\& Periyasamy, L. (2015). Free Radicals: Properties, Sources, Targets, and Their Implication in Various Diseases. Ind J ClinBiochem. 30(1), 11-26. https://www.ncbi.nlm.nih.gov/pubmed/25646037.

Pk, M.M.U., Islam, M.S., Pervin, R., Dutta, S., Talukder, R.I.,\& Rahman, M (2019). Optimization of extraction of antioxidant polysaccharide from Pleurotusostreatus (Jacq.) P. Kumm and its cytotoxic activity against murine lymphoid cancer cell line. PloS one.,14(1), e0209371.https://doi.org/10.1371/journal.pone.0209371

Puttaraju, N.G., Venkateshaiah, S.U., Dharmesh, S.M., Urs, S.M.N.,\& Somasundaram, R. (2006). Antioxidant activity of indigenous edible mushrooms. $J$ Agric food $\quad 9764$ 9772.https://www.ncbi.nlm.nih.gov/pubmed/17177499.

Ramesh, C., Pattar, M.G. (2010). Antimicrobial properties, antioxidant activity and bioactive compounds from six wild edible mushrooms of Western Ghats of Karnataka. IndPhcog Res., 2,107 12.https://www.ncbi.nlm.nih.gov/pubmed/21808550. 
Ramkumar, L., Ramanathan, T., Thirunavukkarasu, P.,\& Arivuselvan, N. (2010). Antioxidant and radical scavenging activity of nine edible mushrooms extracts. Int J Pharmacol., 6(6), 950-953. DOI: 10.3923/ijp.2010.950.953.

Reis, F.A., Martins, A.B., Barros, L.A.,\& Ferreira, I. (2012). Antioxidant properties and phenolic profile of the most widely appreciated cultivated mushrooms: A comparative study between in vivo and in vitro samples. Food and ChemToxicol., 50, 1201-1207. DOI:10.1016/i.fct.2012.02.013.

Reis, F.S., Barros, L., Sousa, M.J., Martins, A.,\& Ferreira, I.C. (2014). Analytica methods applied to the chemical characterization and antioxidant properties of three wild edible mushroom species from northeastern Portugal. Food analytical meth., 7(3), 645-652.https://link.springer.com/article/10.1007/s12161-013-9668-

Ren, L., Yacine, H., Conrad, O.P., Gillian, L., Geoffrey, W.K.,\& Peter, K.B. (2014). Antibacterial and antioxidant activities of aqueous extracts of eight edible mushrooms.BioactCarbohydr Dietary Fibr.,3, 4151.http://dx.doi.org/10.1016/j.bcdf.2014.01.003.

Rich, M.R., Dulay, L.A., Miranda, J.S., Malasaga, S.P., Kalaw, R.G., ReyesChing, T.H. (2016). Antioxidant and Antibacterial Activities of Acetonitrile and Hexane Extracts of Lentinustigrinusand Pleurotusdjamour.Biocatal

Biotechnol.,http://dx.doi.org/10.1016/j.bcab.2016.12.003

Rovensky, J., Stancikova, M., Svik, K., Bauerova, K.,\& Jurcovicova, J.(2011) The effects of $\beta$-glucan isolated from Pleurotus ostreatuson methotrexate treatment in rats with adjuvant arthritis. Rheumatol Int., 31, 507511.https://www.ncbi.nlm.nih.gov/pubmed/20033413.

Salehi, B., Martorell, M.,Arbiser, J.L.,Sureda,A., Martins, N., Maurya,P.K., Sharifi-Rad,M., Kumar, P.,\&Sharifi-Rad, J. (2018). Antioxidants: Positive or Negative Actors? Biomol.,8, 124; doi:10.3390/biom8040124.

Sanchez, C. (2017). Reactive oxygen species and antioxidant properties from mushrooms.Synthetic and Systems Biol., $\quad 2, \quad 13$ 22.https://doi.org/10.1016/j.synbio.2016.12.001.

Selegean, M., Putz, M.V.,\&Rugea, T. (2009) Effect of the Polysaccharide Extract from the Edible Mushroom Pleurotus ostreatus against Infectious Bursal Disease Virus. Intl $J$ Mol Sci.,10, 3616-3634. DOI 10.3390/ijms10083616.

Shahidi, F.,\&Ambigaipalan, P. (2015).Phenolics and polyphenolics in foods, beverages and spices: Antioxidant activity and health effects - A review.Jfunctional foods., 18, 820-897.https://doi.org/10.1016/j.jff.2015.06.018.

Singla, R., Ganguli, A.,\& Ghosh, M. (2010). Antioxidant activities and polyphenolic properties of raw and osmotically dehydrated dried mushroom (Agaricus bisporous) snack food. Int J Food Prop., 13,12901299.https://doi.org/10.1080/10942910903061851.

Srinivasan, M., Rukkumani, R., Ram Sudheer, A.,\& Menon, V.P. (2005). Ferulic acid, a natural protector against carbon tetrachloride-induced toxicity.Fundam Clin Pharmacol., 19, 491-496.https://www.ncbi.nlm.nih.gov/pubmed/16011737. Sudha, G., Vadivukkarasi, S., Shree, R.B.I.,\&Lakshmanan, P. (2012). Antioxidant activity of various extracts from an edible mushroom Pleurotuseous. Food Sci and Biotechnol,. 21(3), 661-668.DOI: 10.1007/s10068012-0086-1.

Suseem, S.R.,\& Saral, A.M.(2013). Analysis on essential fatty acid esters of mushrooms Pleurotus eous and its antibacterial activity.Asian J. Pharmaceut.Clin. Res., 6 ,

191.https://www.researchgate.net/publication/286164625.

Tadhani, M.B., Patel, V.H.,\& Subhash, R. (2007). In vitro antioxidant activities of Steviarebaidiana leaves and callus.J Food Comp and Analy., 20, 323 329.https://doi.org/10.1016/j.jfca.2006.08.004.

Talkad,M.S., Das, R.K., Bhattacharjee, P., Ghosh, S.,\& Shivajirao, U.P. (2015) Establishment of enzyme inhibitory activities of lovastatin, isolated from Pleurotus ostreatus. Int $J$ of Appl Sci Biotechnol.,3(3), 408 416.https://www.researchgate.net/publication/282182618.

Tan, J.B.L.,\&Lim, Y.Y. (2015). "Critical analysis of current methods for assessing the in vitro antioxidant and antibacterial activity of plant extracts," Food Chem., 172, 814-822.https://www.ncbi.nlm.nih.gov/pubmed/25442625.

Thomas, P.A., Geraldine, P.,\& Jayakumar, T. (2014).Pleurotusostreatus, an edible mushroom, enhances glucose 6-phosphate dehydrogenase, ascorbate peroxidase and reduces xanthine dehydrogenase in major organs of aged rats. Pharma Biol., 52(5), 646-654.https://www.ncbi.nlm.nih.gov/pubmed/24392756.

Tong, H., Xia, F., Feng, K., Feng, K., Sun, G., Gao, X., Sun, L., Jiang, R., Tian, D.,\& Sun, X. (2009). "Structural characterization and in vitro antitumor activity of a novel polysaccharide isolated from the fruiting bodies of Pleurotus ostreatus," Biores Technol., $100 \quad$ (4), 1682 1686.https://doi.org/10.1016/j.biortech.2008.09.004.

Valverde, M.E., Hernández-Pérez, T.,\& Paredes-López, O. (2015). Edible Mushrooms: Improving Human Health and Promoting Quality Life. Int $J$ Microbiol.,http://dx.doi.org/10.1155/2015/376387.

Wang, J., Wang, X.H.,\& Ng, T.B. (2007). A peptide with HIV-1 reverse transcriptase inhibitory activity from the medicinal mushroom Russula paludosa. Peptid., 28, 560-565. DOI: 10.1016/i.peptides.2006.10.004

Wang, C.R.., Ng, T.B., Li, L., Fang, J.C., Jiang, Y., Wen, T.Y., Qiao, W.T., Li N.,\&Liu, F. (2011). Isolation of a polysaccharide with antiproliferative, hypoglycemic, antioxidant and HIV-1 reverse transcriptase inhibitory activities from the fruiting bodies of the abalone mushroom Pleurotus abalonus. J. Pharm. Pharmacol., 63, 825-832.https://www.ncbi.nlm.nih.gov/pubmed/21585381.

Wang, J., Hu, S., Nie, S., Yu, Q.,\& Xie, M. (2016). Reviews on Mechanisms of In Vitro Antioxidant Activity of Polysaccharides.Oxidative Med Cellular Long.,http://dx.doi.org/10.1155/2016/5692852.

Wang, Z., Zhou, X., Ren, Y., Wang, R., LuoYang, J., Strappe, P. (2015). Effect of Ganodermalucidum spores intervention on glucose and lipid metabolism gene expression profiles in type 2 diabetic rats. Lipids Health Dis., 14 49.doi: 10.1186/s12944-015-0045-y.

Wasser, S.P. (2011). Current findings, future trends, and unsolved problems in studies of medicinal mushrooms.Appl. Microbiol. Biotechnol., 89, 1323 1332.doi: 10.1007/s00253-010-3067-4

Woldegiorgis, A.Z., Dawit, A., Gulelat, D.H.,\& Gregory, R.Z. (2014) Antioxidant property of edible mushrooms collected from Ethiopia. Food Chem. 157, 30-36. http://dx.doi.org/10.1016/j.foodchem.2014.02.014.

Wong, J.Y.,\& Chye, F.Y. (2009). Antioxidant properties of selected tropical wild edible mushrooms.J Food Comp Analy.,22, 269-277. http://dx.doi.org/10.1016/j.jfca.2008.11.021.

Wu, J.Y., Chen, C.H., Chang, W.H., Chung, K.T., Liu, Y.W., Lu, F. J.,\&Chen, C.H. (2011). Anti-cancer effects of protein extracts from Calvatia lilacina, Pleurotus ostreatusand Volvariellavolvacea. Evid.-Based Complement.Alternat. Med.,https://doi.org/10.1093/ecam/neq057

Xu, N., Gao, Z., Zhang, J., Jing, H., Li, S., Ren, Z.,Wanga, S.,\& Jia, L. (2017) Hepatoprotection of enzymatic-extractable mycelia zinc polysaccharides by Pleurotus eryngii var. tuoliensis. Carbohydr Polym., 157, 196-206. DOI:10.1016/i.carbpol.2016.09.082.

$\mathrm{Xu}, \quad$ X., Yan, H., Chen, J.,\&Zhang, X. (2011).Bioactive proteins from mushrooms.BiotechnolAdv., 29 ,

http://dx.doi.org/10.1016/j.biotechadv.2011.05.003.

Yildirim, N.C., Turkoglu, S., Yildirim, N.,\& Ince, O.K. (2012). Antioxidan propertiesof wild edible mushroom Pleurotus eryngii collected from tuncel province of turkey. Digest Journal of Nanomaterials and Biostructures., 7, 1647-1654.https://www.researchgate.net/publication/290015036.

Zhang, J., Meng, G., Zhang, C., Lin, L., Xu, N., Liu, M., Cui, F.,\& Jia, L. (2015) The antioxidative effects of acidic-, alkalic-, and enzymatic extractable mycelium zinc polysaccharides by Pleurotus djamor on liver and kidney of streptozocininduced diabetic mice. BMC CompleAlternative Med., 15(1), 440.https://www.ncbi.nlm.nih.gov/pubmed/26683206.

Zhang, J.J., Ma, Z., Zheng, L., Zhai, G.Y., Wang, L.Q.,\&Jia, M.S. (2014) Purification and antioxidant activities of intracellular zinc polysaccharides from Pleurotus cornucopiae SS-03. Carbohydrate Polymer., 111, 947-954.doi: 10.1016/j.carbpol.2014.04.074.

Zhishen, J., Mengcheng, T., \&Jianming, W. (1999). The determination of flavonoid contents in mulberry and their scavenging effects on superoxide radicals. Foodchem., 64(4), 555-559.https://doi.org/10.1016/S0308- 